\title{
EU Return Policy and International Human Rights Law: Keeping the balance between border security and human dignity
}

\author{
Belén OLMOS GIUPPONI*
}

\begin{abstract}
This article focuses on the current state of EU immigration legislation and aims to provide a critical analysis in light of international human rights law. Over the past ten years, EU Summits have emphasized the need for the adoption of new legislative measures to converge to a true European common policy on immigration. At present the mainstream debate on immigration in Europe focuses on several different topics. On the one hand, there is the need to secure the borders and control undocumented immigration, while on the other hand there is the question of the protection of migrants' human rights and the improvement of the EU immigration system. There is also a third element, which is EU relations with the immigrants' countries of origin. The current legal framework articulated around the Return Directive sets out the rules and principles to be applied by Member States to third country nationals who do not fulfil, or no longer fulfil, conditions of entry in accordance with EU legislation. I intend to examine the EU return policy in the light of EU law and of international human rights law. In addition, I discuss Italian and Spanish practices in their relations with the countries of origin.
\end{abstract}

Keywords: Human rights - EU Migration Policy - Return Directive - EU external relations - international human rights law

\section{INTRODUCTION}

Over the past ten years migration matters have attracted considerable attention from the Member States at EU level, in particular from those countries which face an increasing flow of immigrants towards their borders, such as Italy and Spain. ${ }^{\mathrm{I}}$

The Amsterdam Treaty (in force since 1999) determined the communitarisation of migration and asylum policies. The various meetings of the European Council between 1999 and 2004 focused on priorities in the governance of immigration. ${ }^{2}$ The Hague Programme (adopted in 2004) attempted to provide a new framework for the management of migration. ${ }^{3}$ Through this Programme, the EU is seeking a more comprehensive approach to dealing with migration. This global approach, as the EU

* PhD. Lecturer in Law (University of Stirling-Scotland). Excerpts of this article were published as Working Paper at the European University Institute (EUI). I would like to thank Professor Francesco Francioni for his valuable comments on a previous version of this paper and Professor Angel Chueca Sancho (in memoriam) for his support in my research on immigration and citizenship. All errors remain, of course, mine. E-mail: maria.olmos@eui.eu.

With regard to the general trends in immigration over the last decade see Global Commission on International Migration,'Report of the Global Commission on International Migration', 31 Population and Development Review (2005) 787 798.

In particular, see Special Tampere European Council (1999), Seville European Council (2002) and Thessaloniki European Council (2003).

The Hague Programme was adopted by the European Council in November 2004, and expressly called for the establishment of common standards for persons to be returned in a humane manner and with full respect for their human rights and dignity. It required the submission of a Commission proposal in early 2005 to rule on the return procedure. The Hague Programme is available at http://europa.eu/legislation_summaries/human_rights/fundamental_rights_within_european_union/116002_en.htm. 
called it, also tries to help the countries of origin to address migration issues. In other words, the global approach aims to build a true partnership with these countries. On the occasion of the adoption of The Hague Programme, the European Council stressed the importance of "the establishment of an effective removal and repatriation policy based on common standards for persons to be returned in a humane manner and with full respect for their human rights and dignity." ${ }^{4}$ It should also be pointed out that the Lisbon Treaty introduced several changes to the common EU migration policy. ${ }^{5}$

EU migration policy is based on the general principles of subsidiarity, proportionality, solidarity and respect for the different legal systems and traditions of the Member States. At the same time, EU legislation must respect human rights and the fundamental freedoms of migrants, as recognized in various international instruments, in particular the 1951 Geneva Convention Relating to the Status of Refugees (hereinafter 1951 Geneva Convention). ${ }^{6}$ In this regard, access to asylum procedures must be guaranteed in those cases in which the requirements are met. But also, undocumented migrants can also be entitled to international protection (subsidiary or complementary) under EU law. According to this concept, when there are people who do not qualify under the 195I Geneva Convention conditions, aside from asylum, other types of international protection can be granted. This is a highly controversial topic, particularly in the case of the arrival en masse of undocumented migrants, in which it is difficult to prove the fulfilment of all the requirements.

Within EU migration and asylum policy, the return policy has become an important component. ${ }^{8}$ Recently, a new Directive on the return of undocumented migrants (Directive 2008/115/EC of the European Parliament and the Council of 16 December 2008 on common standards and procedures in Member States for returning illegally staying third-country nationals, the so-called Return Directive) has set out the various principles to be applied in the expulsion of illegally staying migrants.

This article focuses on an analysis of the recent developments of the EU legislation on migration (and especially, the Return Directive) in the light of international human rights law, in order to assess the present system. In particular, the article addresses the issue of illegal or irregular immigration. ${ }^{9}$ In the first section, the relationship between EU legislation on immigration and international human rights law is examined. The second section is devoted to an analysis of the return policy and the

4 Ibid.

5 One of the main modifications is replacing unanimity in the area of legal migration with qualified majority voting. See S. Peers, 'Legislative Update: EU Immigration and Asylum Competence and Decision-Making in the Treaty of Lisbon', IoEuropean Journal of Migration and Law (2008) 219-247; R. Streinz, 'The European Constitution after the failure of the Constitutional Treaty',63 Zeitschrift für öffentliches Recht (2008) 159-187.

6 Geneva Convention on the status of refugees, available at http://www.unhcr.org/pages/49daoe466.html.

7 This international protection can take the form of "temporary protection" (Directive 2001/55) and "subsidiary protection" (Directive 2004/83) and it is applicable in cases in which the conditions for granting asylum are not satisfied but nevertheless the person concerned is in need of international assistance.

8 See J.P. Cassarino, 'The EU Return Policy: Premises and Implications', MIREM Project paper, EUI, 2007, available online at http://cadmus.eui.eu/bitstream/handle/r8I4/6442/MIREM-RSCAS_RR_2006.pdf?sequence=I.

9 A brief note concerning terminology in this field: there are different expressions to refer to unauthorized migration and illegal aliens; in this paper irregular immigration and undocumented migrants will be used to refer to these respective situations. 
Directive 2008/115/EC on common standards and procedures for returning illegally staying thirdcountry nationals in terms of its compliance with international human rights law. The third section focuses on cooperation on immigration and development with third countries. The author's conclusion is summarized in the fourth section.

\section{EU LEGISLATION ON IMMIGRATION AND INTERNATIONAL HUMAN RIGHTS LAW}

Compliance with human rights standards is one of the most challenging points in the whole EU immigration system. In particular, the question has become controversial regarding irregular immigration. Over the past ten years, the EU has taken various measures to address relevant migration issues, such as the governance of migration flows, the fight against illegal immigration and the fair treatment of third-country nationals. Even though the EU legal responses to immigration have always attempted to keep a balance and guarantee respect for human rights, there are still unsolved questions.

In general terms, the relationship between EU law and international human rights law has gone through several significant changes over the years. Without explaining the whole evolution in detail, it is relevant to highlight the main aspects of the development of this issue at the EU level.

Initially, there were no human rights provisions in the European Community Treaty (hereinafter ECT), but they have been progressively integrated, not only at the internal level within the EU but also at the external level. Internally, human rights issues have become an important part of EU law. ${ }^{\text {IO }}$ Externally, the EU has made human rights issues one of the main pillars of its cooperation with third countries. The Amsterdam Treaty established human rights as one of the primary objectives of EU external policy and, at the same time, it provided for the transfer of the competencies for migration and asylum to the community level.

As the latest development in this field, it should be noted that the Treaty establishing a Constitution for Europe foresaw two considerable changes: the inclusion of the EU Charter of Fundamental Rights in the EC Treaty; and the accession of the EC to the European Convention on Human Rights. These two modifications were, then, incorporated in Article 6 TEU by the Lisbon Treaty.

With respect to the international human rights instruments EU Members States are bound by an array of international instruments devoted to protecting migrants' human rights adopted at the UN level there is, such as the ILO Conventions, the Declaration on the Human Rights of Individuals Who Are Not Nationals of the Country in Which They Live (1985); the 195I Geneva Convention Relating to the Status of Refugees; the 1989 Convention on the Rights of the Child; and the Convention on the Protection of Migrant Workers and the members of their Families (1990). In addition, the Protocol to prevent, suppress and punish trafficking in persons, especially women and children, supplementing the United Nations Convention against Transnational Organized Crime (known also as "Palermo Protocol"); the Council of Europe Convention on Action against Trafficking

\footnotetext{
Io On this particular issue, see P. Alston (Ed.), The EU and buman rights (OUP, London, 1999).
} 
of Human Beings; and, concerning immigration by sea, the United Nation Convention on the Law of the Sea of 1982 (UNCLOS), the International Convention for the Safety of Life at Sea of 1974 (SOLAS) and the International Convention on Maritime Search and Rescue of 1979 (SAR) ${ }^{\mathrm{II}}$ should be mentioned. These constitute the normative basis upon which EU Law has to regulate immigration. Consequently, EU Law on immigration has to show compliance with international human rights standards. The core concept of dignity and basic rights (minimum standard) are also essential in this field.

In this regard, it should be pointed out that EU members States have become parties to the main international instruments on human rights. Even so, EU Member States, as mainly receiving countries, have not yet ratified the Convention on the Protection of the Rights of All Migrant Workers and Members of Their Families. ${ }^{\text {I2 }}$

At the regional level, EU law also has to meet the human rights requirements laid down in the European Convention on Human Rights and the other relevant instruments adopted within the framework of the Council of Europe. ${ }^{13}$ The Court of Justice of the European Union, through its caselaw and the Advisory Opinion issued on the accession of the EC to the European Convention on Human Rights, highlighted the relevance of the observance of international human rights law, and particularly those instruments adopted within the framework of the Council of Europe, within the whole EU legal system. ${ }^{\mathrm{I}}$

The European Court of Human Rights (hereinafter: ECHR) has also expressed its opinion on the EU immigration system on several occasions. ${ }^{\text {Is }}$ Indeed, in the Strasbourg jurisprudence there have been cases before the ECHR involving the protection of the human rights of undocumented migrants. ${ }^{16}$

II The UN Palermo Protocol was adopted by resolution GA/RES/55/25 of is November 2000 at the fifty-fifth session of the General Assembly of the United Nations and entered into force on $25^{\text {th }}$ December 2003. The Protocol is available at http://www.unodc.org/unodc/treaties/CTOC/.The Council of Europe Convention on Action against Trafficking of Human Beings was adopted on 16.05 .2005 and came into force on or.02.2008. The Convention is available at http://conventions.coe.int/Treaty/EN/Treaties/Word/r97.doc. These international human rights instruments guarantee a minimum level of protection to every human being and to every migrant.

I2 International Convention on the Protection of the Rights of All Migrant Workers and Members of Their Families, its status of ratification and declarations and reservations are available at http://treaties.un.org/Pages/ViewDetails.aspx?src=TREATY\&mtdsg_no=IV-I3\&chapter=4\&lang=en.

13 The European Convention on Human Rights is available at: http://www.echr.coe.int/ECHR/EN/Header/Basic+Texts/Basic+Texts/The+European+Convention+on+Human+Rights+a nd+its+Protocols/. The European Convention for the Prevention of Torture and Inhuman or Degrading Treatment or Punishment, is available at http://conventions.coe.int/Treaty/en/Treaties/Html/126.htm The Council of Europe Convention on Action against Trafficking in Human Beings is available at http://conventions.coe.int/Treaty/EN/Treaties/Html/197.htm.

${ }_{14}$ Advisory Opinion 2/94 issued by the Court of Justice on $28^{\text {th }}$ March 1996. See C. Escobar Hernández, 'Comunidad Europea y Convenio Europeo de Derechos Humanos. ¿El fin de una vieja polémica? (Comentario al Dictamen 2/94 del TJCE, de 28 de marzo de 1996)', 23 Revista de Instituciones Europeas (1996) 817-838.

is See, for instance, the Case Mubilanzila Mayeka and Kaniki Mitunga vs. Belgium, Sentence I2 October 2006.

16 Among others, it is relevant to highlight the following decisions: Üner v. the Netherlands, ECHR (2006), Grand Chamber, Application no. 46410/99 (Article 8); Saadi v. Italy, ECHR (2008), Grand Chamber, Application no. $37201 / 06$ (Article 3); N. v. the United Kingdom, ECHR (2008), Grand Chamber, Application no. 26565/05 (Article 3); Saadi v. the 
In the field of the protection of foreign nationals, the European Convention is complemented by some additional protocols which are relevant to this topic: Protocol 4 (which contains the prohibition of the collective expulsion of aliens); Protocol 7; and Protocol in (which is related to the principle of non-discrimination). In addition, other international instruments adopted by the Council of Europe address this question, such as the European Social Charter and the Convention for the Prevention of Torture and Inhuman or Degrading treatment or Punishment. It is also worth mentioning that the Council of Europe has adopted a specific treaty, the European Convention on the Status of Migrant Workers (1977). ${ }^{17}$

Under the ECHR there are certain rights that are regarded as core, or non-derogable. Among these absolute rights are included the right to life (Article 2), the prohibition of torture and inhuman and degrading treatment or punishment (Article 3), the prohibition of slavery and servitude (Article 4.I), and the prohibition of retroactivity of punishment (Article 7). ${ }^{18}$ The case law of the former Commission and the jurisprudence of the ECHR set the guidelines on the application of the ECHR with respect to the rights of foreigners in general, and those who are unlawfully staying in a State (in an irregular situation) because have entered illegally (illegal entrants) or stayed beyond their permission (overstaying foreigners). ${ }^{19}$

So far, the EU has attempted to regulate different statuses concerning foreigners (non-EU citizens)..$^{20}$ Among them, the most complete is the status of long-term residents in a Member State, whereas the legal status granted to an irregular migrant is still uncertain. ${ }^{2 I}$

Within the EU, there has been a constitutionalization ${ }^{22}$ of non EU-Citizens' rights through the adoption of different instruments such as: the Council Directive 2003/86/EC of 22 September 2003 on the right to family reunification; the Council Directive 2003/109/EC of 25 November 2003 concerning the status of third-country nationals who are long-term residents; the Council Directive 2004/83/EC of 29 April 2004 on minimum standards for the qualification and status of third country nationals or stateless persons as refugees or as persons who otherwise need international protection and the content of the protection granted; the Council Directive 2004/II4/EC of I3 December 2004 on the conditions of admission of third country nationals for the purposes of study, pupil exchange, unremunerated training or voluntary service; and the Council Directive 2005/85/EC of I December

United Kingdom, ECHR (2008), Grand Chamber, Application no. 13229/03 (Article 5); C.G. and Others v. Bulgaria ECHR (2008), 5th section, Application no. $1365 / 07$ (Article 8, I3, article I of Protocol No. 7).

${ }_{17}$ The Convention was opened for signature on 24 November 1977, and entered into force on Ist May 1983. The text is available at http://conventions.coe.int/Treaty/Commun/QueVoulezVous.asp? NT=093\&CM=I\&DF=today \&CL=ENG. Currently in States are parties to the Convention.

I8 See H. Lambert, The position of aliens in relation to the European Convention on Human Rights (Council of Europe, Strasbourg, 2006), at 27.

is On the jurisprudence of the ECHR, see H. Lambert, ibid.

20 It is interesting to recall that there are different agreements signed with non-EU countries, according to which their citizens enjoy different levels of rights.

гा See M.B. Olmos Giupponi, 'The rights of undocumented migrants in the light of the recent international practice in Europe and America', Max Weber Working Papers 2009/03, available at http://cadmus.eui.eu/bitstream/handle/I814/10728/MWP_2009_03_Rev.pdf?sequence=3.

${ }_{22}$ S. Lavenex, 'Towards the constitutionalization of aliens' rights in the European Union?', I3 Journal of European Public Policy (2006), I284- I30I. 
2005 on minimum standards on procedures in Member States for granting and withdrawing refugee status.

It is also relevant to briefly examine the case law of the European Court of Justice on migration issues. In the early cases (sentences issued between the 1970's and 1990's), the European judiciary body had the opportunity to judge various cases concerning mainly family reunification and lawful immigration. ${ }^{23}$ The recent case law shows that the Court of Justice and its human rights concerns focus more on internal movement aspects than on the crossing of external borders. ${ }^{24}$ For instance, in the case Consequently, the response of the Court of Justice to illegal immigration is not complete. Indeed, case law barely gives any sort of guidelines or principles to be applied in the case of undocumented migrants. In El Dridi $v$ Italy (20II) dealing with the application of the return directive, the Court underlined that "national legislation imposing a prison sentence on illegally staying thirdcountry nationals solely on the grounds of refusal to obey an order to leave the territory within the time limit given is contrary to Directive $2008 / \mathrm{II} / \mathrm{EC}$ on common standards and procedures in Member States for returning third-country nationals". 25

At EU policy level, the scenario is even more complex. With the increase in immigration flows in recent years the whole situation has become more difficult to manage in practice. The number of undocumented migrants trying to enter EU territory has fluctuated between 50,000 and 100,000 per year since $2000 .{ }^{26}$ In recent years, the EU has also had to face enlargement, which implies opening internal borders to free the movement of persons (citizens from the new EU Member States) and controlling the new common external borders.

In the design of a common European immigration and asylum system, four main priorities can be identified: the adoption of a common EU asylum system; the establishment of adequate treatment of third country nationals; and the governance of migration flows and the development of partnerships with the countries of origin.

One of the main achievements is the adoption of a common asylum policy on the basis of the $195 \mathrm{I}$ Geneva Convention and the application of the principle of non-refoulement. ${ }^{27} \mathrm{EU}$ asylum policy is

23 Case 267/83, Diatta v Berlin Land [1985] ECR 567; Case 12/86, Demirel v Stadt Schwäbisch Gmünd 1987 [ECR] 3719; Cases C-72/91 and C-73/91 Sloman Neptum [1993] ECR 1887; Case C-416/96, Nour Eddline El-Yassini v. Secretary of State for Home Department, [1999] ECR I-I209 andCase C-459/99Third country nationals who are the spouse of a Member State national - Requirement for a visa - Right of entry for spouses not in possession of identity documents or a visa - Right of residence for spouses who have entered unlawfully - Right of residence for spouses who have entered lawfully but whose visa has expired when they apply for a residence permit - Directives 64/22I/EEC, 68/360/EEC and 73/148/EEC and Regulation (EC) No 2317/95 [2002] ECR I-659I.

24 See, for instance, Case Calfa [1999] ECR I-II; C-Ioo/o, Case Olazabal [2002] ECR I-I098I; C-482/or and C-493/or Orfanopolous and Olivieri [2004] ECR I-5257; and C-44I/02 Commission v. Germany [2006] ECR I-344916; Case C-459/99 MRAX [2002] ECR I-659I and C-I27/08 Metock and others [2008] ECR I-624I.

${ }_{25}$ Case C-6I/II PPU, Hassen El Dridi Reference for a preliminary ruling: Corte d'appello di Trento - Italy [20II] ECR I-oooo, Judgment of the Court (First Chamber) of 28 April $201 \mathrm{I}$.

26 I. Kaya, 'Undocumented Migration: Counting the Uncountable. Data and Trends across Europe', December 2008, Clandestino project, at 26.

27 The EU policy on asylum comprises the following relevant legislation: II.07.2007 862/2007/EC: Regulation of the European Parliament and of the Council of II July 2007 on Community statistics on migration and international protection and repealing Council Regulation (EEC) No $3 \mathrm{II} / 76$ on the compilation of statistics on foreign workers, Official Journal L 199, 31.07.2007, p. 23-29.; 05.10.2006 2006/688/EC: Council Decision of 5 October 2006 on the establishment of a mutual 
based on respect of this principle, which is embodied in the Geneva Convention and recognized as a core human right under the ECHR. ${ }^{28}$ However, it should be underlined that article 33 of the Geneva Convention as a main provision in this field has become less significant in comparison with article 3 ECHR, which prohibits torture and inhuman or degrading treatment. The European Court of Human Rights has emphasized that the ECHR provides for a higher level of protection than that offered by the Geneva Convention on refugees. In fact, while article 33 of the Geneva Convention can be subject to derogations, Article 3 ECHR is considered absolutely inderogable. ${ }^{29}$

EU immigration policy also focuses on granting fair treatment to third country nationals, which implies the recognition of rights and obligations for migrants, as well as the development of special measures against discrimination and xenophobia. As another priority, the management of immigration flows aims to establish legal channels for immigration and, at the same time, to combat illegal immigration. Closely linked to this point, it is crucial to develop partnerships with the countries of origin and include migration issues in the bilateral or multilateral dialogue in order to

information mechanism concerning Member States' measures in the areas of asylum and immigration, Official Journal L 283 , I4.I0.2006, p. 40-43; 21.02.2006 2006/I88/EC: Council Decision of 2I February 2006 on the conclusion of the Agreement between the European Community and the Kingdom of Denmark extending to Denmark the provisions of Council Regulation (EC) No 343/2003 establishing the criteria and mechanisms for determining Member State responsible for examining an asylum application lodged in one of the Member States by a third-country national and Council Regulation (EC) No 2725/2000 concerning the establishment of Eurodac for the comparison of fingerprints for the effective application of the Dublin Convention, Official Journal L 066, 08.03.2006, p. 37-37; I3.12.2005 Council Directive 2005/85/EC of I December 2005 on minimum standards on procedures in Member States for granting and withdrawing refugee status, Official Journal L 326, I3/12/2005 p. 13; 30.09.2004 Council Directive 2004/83/EC of 29 April 2004 on minimum standards for the qualification and status of third country nationals or stateless persons as refugees or as persons who otherwise need international protection and the content of the protection granted, Official Journal L 304, 30/09/2004 p. 00I2 - 0023; 25.02.2003 Council Regulation (EC) No 343/2003 of I8 February 2003 establishing the criteria and mechanisms for determining the Member State responsible for examining an asylum application lodged in one of the Member States by a third-country national, Official Journal L 050, 06/02/2003 p. 000I - o010, Entry into force: I6 March 2003; 06.02.2003 Council Directive 2003/9/EC of 27 January 2003 laying down minimum standards for the reception of asylum seekers, Official Journal L 031, 06/02/2003 p. 0018 - 0025; 05.03.2002 Council Regulation (EC) No 407/2002 of 28 February 2002 laying down certain rules to implement Regulation (EC) No 2725/2000 concerning the establishment of "Eurodac" for the comparison of fingerprints for the effective application of the Dublin Convention, Official Journal L 062, 05/03/2002 p. 000I - 0005; 20.07.200I Council Directive 200I/55/EC of 20 July 200I on minimum standards for giving temporary protection in the event of a mass influx of displaced persons and on measures promoting a balance of efforts between Member States in receiving such persons and bearing the consequences thereof, Official Journal L 212, 07/08/200I p. 00I2 - 0023; 15.12.2000 Council Regulation (EC) No 2725/2000 of II December 2000 concerning the establishment of 'Eurodac' for the comparison of fingerprints for the effective application of the Dublin Convention, Official Journal L 316, I5/12/2000 p. 000I - ooro.

${ }_{28}$ The Geneva Convention was considered the main pillar in the design of the EU asylum policy. EU regulations focused on the adoption of common standards and the definition of the criteria for granting refugee status to asylum seekers. In the EU asylum policy, non-refoulement plays a relevant role in its shaping. There has been scholarly discussion about the nature of non-refoulement, with partial agreement on the jus cogens character. Internally, too, national courts have recognized the value of the principle of non-refoulement. See the case Ali Mohamed Hussain, Judgement of the Italian "Corte di Cassazione" issued on 17 November 2008, available at http://www.anolf.it/archivio/download/sent._corte_cass._I7_II_08.pdf.

${ }_{29}$ The ECHR has affirmed the absolute nature of Art. 3 in various cases, such as Chabal vs. United Kingdom(1996) V, no. 22. On that occasion, the Strasbourg Court emphasized that: "Article 3 enshrines one of the most fundamental values of democratic society (...) even in those circumstances, the Convention prohibits in absolute terms torture or inhuman or degrading treatment or punishment, irrespective of the victim's conduct (...) Article 3 makes no provision for exceptions and no derogation from it is permissible under Art. Is even in the event of a public emergency". See Chabal vs. United Kingdom, supra n.29. 
achieve joint migration management and readmission in cases of illegal immigration. This cooperation in migration-related aspects with third countries includes also an element of economic cooperation to improve development in the countries of origin. As can be observed, there is constant reference to the need to combat irregular immigration on the EU's immigration agenda, however sometimes it seems that the human rights aspects are overlooked in the design of the policy. In fact, one of the main concerns nowadays is how to reconcile EU migration policy when fighting illegal immigration (which also includes the return policy) with the safeguarding of human rights, as will be appreciated from the following paragraphs.

\section{THE EU IMMIGRATION SYSTEM AFTER THE RETURN DIRECTIVE: KEEPING THE DELICATE BALANCE BETWEEN BORDER SECURITY AND HUMAN RIGHTS OBLIGATIONS}

Over the past decade, the return policy has become one of the most frequently addressed topics in the realm of EU immigration..$^{30}$ The main steps in the adoption of a common policy in this field were:

- Communication on a Common Policy on Illegal Immigration (I5 November 200I). In this document the Commission pointed out that return policy is an integral and crucial part of the fight against illegal immigration. The document also makes it explicit that the return policy needs to be founded on three elements: common principles, common standards and common measures.

- Green Paper on a Community Return Policy (Io April 2002). This document developed the issue of return as an integral part of a comprehensive Community Immigration and Asylum Policy. It highlighted the need for approximation and improved co-operation on return among Member States. Furthermore, the document provided a number of possible elements for a future legislative proposal on common standards in order to generate a broad debate among the relevant

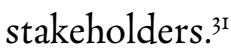

- Return Action Programme (28 November 2002). It called for improved operational co-operation among Member States, intensified cooperation with third countries, and the establishment of common standards with the aim of facilitating operational return.

As underlined previously, since the adoption of The Hague Programme, the EU has pursued a global approach in the field of immigration, aimed at building up a proper European common policy on immigration. However, the articulation of a coherently implemented policy has proven to be a difficult task as can be appreciated in the following paragraphs. ${ }^{22}$

In this new EU strategy, Member States agreed on the need for more coherence. As declared in The Hague Programme, "The Union aims at developing a balanced approach: it implies the establishing of a common immigration policy, covering admission procedures and criteria to legally enter its territory, and ensuring a secure legal status and a better defined set of specific rights to third

30 See A. Chueca Sancho, 'Derechos Migración y Derechos Humanos: El Marco General', CEIB (20II) available at https://www.urjc.es/ceib/espacios/migraciones/seminario-expertos/documentos/Capitulo_o2.pdf.

3I This Green Paper is available at http://aei.pitt.edu/38190/I/COM_(2002)_I75.pdf.

32 See J. A. González Vega, ‘Regreso al futuro? La difícil concreción de una política europea de inmigración', in F. Aldecoa Luzárraga (ed), Los Tratados de Roma en su cincuenta aniversario perspectivas desde la Asociación Española de Profesores de Derecho Internacional y Relaciones Internacionales (Marcial Pons, Madrid, 2008). 
country nationals temporarily working or staying legally for other reasons in the EU, while carrying out a policy against illegal migration, which is both firm yet respectful of the rights and dignity of third country nationals, including those in an irregular situation in the Union." ${ }_{33}$

\section{(I) The Return Directive}

Within this general framework, and after a long period of negotiations, in 2008 the Council and the Parliament adopted the Directive of the European Parliament and the Council on common standards and procedures in Member States for returning illegally staying third-country nationals (hereinafter referred to as the Return Directive or the Directive) as part of this new EU immigration approach.34 The most hotly debated questions during the negotiation were those related to the protection of human rights.

In general, the Directive aims to establish fair common rules concerning return, removal, the use of coercive measures, temporary custody and re-entry in the case of illegally staying third-country nationals, which fully take into account respect for the human rights and fundamental freedoms of the persons concerned..$^{35}$ In other words, the main scope is to lay down minimum standards for the fair treatment of undocumented migrants during the return procedure. ${ }^{36}$

As usual in EU instruments concerning the protection of individuals, under the Directive, Member States are not allowed to apply harsher rules to illegal immigrants, and on the contrary they are authorized to maintain or adopt more generous rules. Moreover, this EU legislation applies in any case only after a decision has been taken by the national authorities to deport an illegal immigrant: each Member State retains the power to decide in the first place whether it wishes to regularise or deport the immigrant, in fact the Directive pays special attention to the exercise of sovereign powers by the Member States.

So far, only positive aspects of the adoption of this Directive have been considered. However, since the EU announced its adoption, there have been critical responses from several human rights organizations in Europe. Their underlying concerns regard compliance with international human

33 See The Hague Programme, supra n. 3.

34 The Commission drafted the legislative proposal in 2005, and after almost three years of intense negotiations the Directive reached a compromise between the European Parliament and the Council. It was approved on first reading by the full Parliament on $18^{\text {th }}$ June 2008. The draft directive was adopted by the European Parliament under the co-decision procedure by 369 votes to 197, with 106 abstentions. There were different Presidencies of the Council during the negotiation of the proposal: the most important was the French Presidency under which the Directive was approved. The European Parliament's Rapporteur was Manfred Weber. On the negotiation of the Directive see D. Acosta, 'The Good, the Bad and the Ugly in EU Migration Law: Is the European Parliament Becoming Bad and Ugly? (The Adoption of Directive 2008/II5: The Returns Directive)' II European Journal of Migration and Law (2009) 19-39.

35 Various provisions in this area had been adopted before, for example Council Directive 2003/110/EC of 25 November 2003 on assistance in cases of transit for the purposes of removal by air, and Council Decision 2004/573/EC of 29 April 2004 on the organisation of joint flights for removals represent first important legal milestones. Directive 200I/40/EC on mutual recognition of decisions on the expulsion of third-country nationals, in combination with Council Decision 2004/191/EC setting out the criteria and practical arrangements for the compensation of financial imbalances, provides for a legal framework for mutual recognition of expulsion decisions.

36 With regard to the legislation, measures and policies on removals adopted by each EU Member State, see IOM, Return Migration: Policies and Practices in Europe, IOM, Geneva, 2004. 
rights law, and in particular the application of the 195I Geneva Convention Relating to the Status of Refugees and the 1989 Convention on the Rights of the Child.

In the following paragraphs, the main aspects of the return procedure will be examined, according to the regulation provided for the Directive.

\section{(a) The return decision}

In the words of the Directive, return is "the process of a third country national going back (...) to his or her country of origin, or a country of transit in accordance with Community or bilateral readmission agreements or other arrangements, or another third country, to which the third-country national concerned voluntarily decides to return and in which he or she will be accepted" (Article 3.3). Under the Directive, the previous grounds on which the return decision is based is the "illegal stay" of the migrant. The definition of which categories of migrants are covered under the scope of the Directive is uncertain. The main category comprises those who are already present in the territory of the State for a period. But the Directive's application is not clear with regard to migrants who are apprehended at, or in proximity to, the border. Under the directive, Member States can decide to exclude from its scope third-country nationals "who are apprehended or intercepted by the competent authorities in connection with the irregular crossing by land, sea, air of the external border of a Member State and who have not subsequently obtained an authorisation or a right to stay in that Member State (article 2. 2. a). ${ }^{37}$ This could lead to different degrees of protection..$^{8}$

Member States are required under the Directive to issue a return decision to every third-country national illegally staying on their territory (article 6.I). This return decision should include measures to enforce return, which may include a separate removal order in the case that the third-country national concerned fails to leave. However, there are certain cases in which the return decision does not proceed:

- when the irregular migrant has a valid residence permit or entitlement to lawful residence in another Member State, he or she would only be expelled in cases of non-compliance with the obligation to return to the second Member State or for reasons of national security or public policy (article 6.2);

- if there are bilateral agreements or other arrangements and an irregular migrant can be taken back by another Member State. This second Member State has to enforce the return of the person concerned (article 6.3);

- in cases in which an application for renewal or a permit to stay are pending, the Member States may consider abstaining from adopting a return decision (article 6.5).

37 This is a matter of interpretation. In Spain there are situations that may not fall into the Directive's scope, for instance, when the foreigner intends to illegally enter in the country (Art. 58.3,b Immigration Act) or when it is intercepted in the border or nearby (Art. 23.I,b Immigration Act),. Also the cases what now is called "regreso" (Art. 26.2 Immigration Act). See, in detail F.J. Enériz Olaechea, 'Los procedimientos administrativos de expulsión, devolución y retorno de extranjeros', in J.F. Alenza García, y J.A. Razquin Lizarraga (eds), Organización y procedimientos administrativos: libro bomenaje al profesor Francisco González Navarro (Aranzadi, Madrid, 2007) 589-624.

${ }_{38}$ D. Acosta in analysing the original proposal from the Commission indicates two still unanswered questions: (i) Who are the third-country nationals covered by the Directive and who are not? (ii) What is the protection granted, if any, to those not included in the scope? supra n. 34, at 26. The italics are ours. 
- This return decision ends the illegal stay and opens the next phase, in which the person has the possibility of voluntary departure. The person concerned can be returned to different places:

- his or her country of origin, or

- a country of transit in accordance with Community or bilateral readmission agreements or other arrangements, or

- another third country, to which the third-country national concerned voluntarily decides to return and in which he or she will be accepted. ${ }^{39}$ Importantly, it should be underlined that in any case, the consensus of the person concerned is necessary..$^{40}$

In the original draft there was an explicit reference to human rights and the need for the Member States to adopt return decisions in accordance with their human rights obligations, ${ }^{4 \mathrm{I}}$ as derived in particular from the European Convention on Human Rights, the right to non-refoulement, the protection of children's rights and to family unity. These explicit references to fundamental rights obligations have been removed from the main text and reallocated in the preamble (see paragraphs 2I to 24 ) and make the obligatory character of the return decision particularly problematic. ${ }^{42}$

\section{(b) Detention period}

According to the legislative text adopted, the expulsion of an undocumented migrant will follow two steps:

- Voluntary departure period: In this new legislative approach when an expulsion order is taken, the undocumented migrant will be given the possibility of voluntary departure for a limited period (between seven and thirty days). In the event that the migrant concerned (the deportee) does not voluntarily leave EU territory, the authority will issue a removal order.

- Removal order and custody period: Once a removal order is issued there can be two possibilities. First of all, if the authority which issued the removal order is judicial and there are grounds to believe that the person is likely to escape, he or she can be placed in custody for a maximum period of six months, which can be extended, in certain cases, up to eighteen months. At this point, it is relevant to underline that previously in some EU Member States an undocumented migrant could be detained for either a longer period or even for an indefinite period. ${ }^{43}$ Secondly, if

\footnotetext{
39 Return Directive, Art. 3.3.

$4^{\circ}$ A. Baldaccini, 'The Return and Removal of Irregular Migrants under EU Law: An Analysis of the Returns Directive' IIEuropean Journal of Migration and Law(2009), I-I7.

${ }^{4}$ The International Organisation for Migration (IOM) has prepared a specific document about the return procedure: Return migration - Policies and Practices in Europe(Geneva, 2004), available at: http://www.ch.iom.int/fileadmin/media/pdf/publikationen/return_migration.pdf.

${ }^{42}$ A. Baldaccini, supra n. 40, at 7.

43 Take for instance the case of the United Kingdom, in which there is no maximum, even though the Directive is not applicable to this specific country as will be shown later on. During the negotiation of the Directive text there was a proposal, which was not approved, by the PES group to reduce this custody period to three months plus a further three months.
} 
the undocumented migrant is placed in custody following a decision taken by an administrative authority, this decision has to be confirmed by the courts "as speedily as possible." 44

In the case of children and families, the Directive also states that they must not be subject to coercive measures and can only be held in custody as a last resort. Unaccompanied minors may only be deported if they can be returned to their family or to "adequate reception facilities" in the state to which they are sent.

\section{(c) Probibition of re-entry to EU territory}

With regard to the prohibition of re-entry, this applies for a maximum of five years if the person is deported after the voluntary return period, ${ }^{45}$ but it can be issued for a longer period if the individual represents a serious threat to public safety. It is important to note that Member States retain the right to waive, cancel or suspend these bans.

\section{(d) Special provision on emergency situations}

The text approved also includes an article that provides for more flexibility for Member States when they face "emergency situations," in other words when an "exceptionally large number" of thirdcountry nationals creates "an unforeseen heavy burden" on the administrative or judicial capacity of a Member State. ${ }^{46}$ In this case, the State involved may decide to allow longer periods for judicial review as well as less favourable conditions of detention. However, the State must take into account the situation of the individual's country of origin, under the principle of non-refoulement.

Turning now to the main areas of controversy, three different orders of questions will be analyzed:

(i) The Return Directive and international human rights law

In the Directive, there is a clear aim to make the removal procedure more efficient and at the same time to protect the rights of the people involved. ${ }^{47}$ Despite all these efforts to defend the rights of undocumented migrants during the removal procedure, certain concerns remain. In the original draft, there was an explicit mention of the subjection of the Member States' power when issuing a return decision to fundamental rights (and in particular the right to non-refoulement, children's rights and the right to family unity) as established by the European Convention on Human Rights. In order to correctly assess the compliance of the Directive with human rights standards we will consider the initial situation concerning the removal of undocumented migrants, the debate during the negotiations, and the scenario after the adoption of the Directive.

44 In the original draft the court order was required within 72 hours. The EP Civil Liberties Committee wanted 48 hours while the PES group tabled an amendment to restore the deadline of 72 hours. These two latter proposals were rejected.

45 Return Directive. Art. II.

46 Return Directive. Art. I8. This article was added by the Council.

47 A. Baldaccini, supra n. 40. 
EU Member States have set up various mechanisms for removing and holding undocumented migrants. The length of detention ranges from 32 days to unlimited periods.$^{48}$ On the whole, many of these systems barely fit within legal frameworks, and in certain cases the norms for detention conditions are not defined. Two different situations can be distinguished. On the one hand, we find Member States with a long tradition of receiving immigration flows, which have had to cope with the arrival of migrant populations for decades. They have thus developed and adapted systems for the removal of undocumented migrants for a long time. On the other hand, we can mainly observe in the case of southern European countries that, apart from dealing with inter-European migration, they are also gateways into the European Union from the south. They therefore have to face the arrival, for the most part by sea, of migrants and asylum seekers coming mainly from Asia and Africa. These countries have developed systems for detention "on arrival".

As observed earlier, the text submitted by the Commission aimed to harmonise legislation on the detention and expulsion of people in an "illegal" situation at a European level. Traditionally, all the measures involving the expulsion of an undocumented migrant were under the sovereignty of each Member State. Therefore, there was a heterogeneity of different legal solutions adopted at the national level.

During the negotiation, various NGOs and the Committee on Civil Liberties of the Parliament (hereinafter LIBE Committee) participated with different proposals. Many human rights organizations raised various issues. ${ }^{49}$ In their common proposals, they recommended a list of "common principles on the removal of migrants in an irregular situation and rejected asylum seekers," stressing that these fundamental principles should be prevalent in the drawing up of any expulsion policy, in particular the European Directive on returns. ${ }^{50}$

According to Amnesty International, the Return Directive establishes "an excessive period of detention of up to I.5 years as well as an EU-wide re-entry ban for those forcibly returned, risks lowering existing standards in the Member States and sets an extremely bad example to other regions in the world." ${ }^{1}$

The main argument behind the different reports issued during the negotiation period highlighted that those migrants who are in an irregular situation and rejected asylum seekers are not well-

${ }_{48}$ This is an area in which Member States have regulated the measures to be taken in the management of migratory flows in accordance with their geographical, political and economic situations.

49 Different European human rights organizations (Amnesty International Europe, Jesuit Refugee Service Europe, ECRE, Caritas Europe, PICUM, Human Rights Watch, CCME, Save The Children, Sensoa, Quakers, FCEI, Spanish Evangelical Church) held a consultation process during the period of the negotiation of the Directive (2005-2008). See, also: Proposal for a "return" Directive. The FIDH calls for the suspension of the text's adoption until it conforms to Member States international human rights obligations, available at: http://www.statewatch.org/news/2008/may/eu-fidh-returnsdirective.pdf.

so Human Rights Watch, Common Principles on Removal of Irregular Migrants and Rejected Asylum Seekers, August 2005, available at http://www.unhcr.org/refworld/docid/437dd5304.html.

${ }_{51}$ Amnesty International. Report issued on the EU Return Directive (2008), excerpts available at http://euobserver.com/justice/26354. See, also,'Proposal for a "returns” Directive. The FIDH calls for the suspension of the text's adoption until it conforms to Member States international human rights obligations', available at: http://www.statewatch.org/news/2008/may/eu-fidh-returns-directive.pdf. 
protected against expulsion and detention. In other words, the Directive does not grant an adequate level of protection.

In its report, the LIBE committee stated that Member States are bound to respect the principles recognized in international instruments and their international obligations, among them the nonrefoulement of asylum seekers (1951 Geneva Convention); the best interests of the child (1990 International Convention on the Rights of the Child) and the protection of private and family life (article 8 of the European Convention on Human Rights). Nevertheless the LIBE committee did not propose specific provisions to guarantee their implementation in effective terms.

Expulsion cases raise concern at the European Court of Human Rights with regard to the fulfilment of Article 3 of the European Convention on the Protection of Human Rights. This has been and is one of the core issues in the Strasbourg jurisprudence..$^{52}$ In the case of expulsion, many human rights can be involved, which are, under the ECHR, "non-derogable." Furthermore, the Lisbon Treaty has incorporated the EU Charter of Fundamental Rights into primary law and provided for the EU's accession to the ECHR reinforcing the protection of human rights at EU level.53

As stated before, there are core human rights that must be respected in any case: ${ }^{4}$

- the right to life;

- the right to liberty and security of the person;

- the prohibition of torture, or other cruel, inhuman or degrading treatment or punishment;

- the prohibition of genocide;

- the prohibition of slavery;

- the prohibition of racial discrimination;

- the right not to be convicted or punished under retroactive laws;

- the right to private life and family;

- the freedom of conscience, thought, and religion;

- the right of access to a due process of law.55

These are rights that stem largely from customary international law, falling into the category of jus cogens. ${ }^{56}$ As G. S. Goodwin-Gill and K. Newland point out, "these rights (...) may not be derogated

52 See, for instance, Mohamed Zamir v. United Kingdom Case No 9174/80; Case Chahal see supra n. 29.

53 In addition to Art. 2 of the Treaty on European Union (TEU) which provides that 'the Union is based on the values of respect for human dignity [...] and respect for human rights, including the rights of persons belonging to minorities'; Art. 6 TEU reads: 'The Union recognises the rights, freedoms and principles set out in the Charter of Fundamental Rights of the European Union of [...] which shall have the same legal value as the Treaties.' 'The Union shall accede to the European Convention for the Protection of Human Rights and Fundamental Freedoms.' 'Fundamental rights, as guaranteed by the European Convention for the Protection of Human Rights and Fundamental Freedoms and as they result from the constitutional traditions common to the Member States, shall constitute general principles of the Union's law.'

54 On the rights of foreigners see United Nations, The Rights of Non-citizens (Office of the United Nations High Commissioner for Human Rights, New York and Geneva, 2006).

55 On the rights which cannot be derogated, see G. S. Goodwin-Gill and K. Newland, 'Forced migration and international law', in T. A. Aleinikoff and V. Chetail (eds) Migration and International Legal Norms (Asser Press; Ist Edition. Edition, The Hague, 2003).

56 A. Bianchi, 'Human Rights and the Magic of Jus Cogens', 19Eur J Int Law (2008), 49I-508. The Inter-American Court of Human Rights in its Advisory Opinion I8/03 has upheld the jus cogens nature and erga omnes effect of human rights norms protecting undocumented migrants. For a detailed analysis, see M. B. Olmos Giupponi, 'Avances recientes del Sistema 
(...) even in exceptional circumstances; they benefit everyone, national, foreigners, migrants, and refugees whether lawfully or unlawfully in the state, and regardless of any situation of emergency." ${ }^{57}$ In the removal process (as regulated in the Return Directive) there are points to be clarified in order to guarantee the respect of human rights, especially taking into account the vulnerability of the undocumented migrant who faces the trafficking and smuggling of individuals.

In the following paragraphs, some key points in the Directive which involve the protection of human rights will be examined:

(ii) The length of detention (I8 months)

One of the delicate aspects is the period between the adoption of the removal order and its enforcement. As we have seen in a previous paragraph, detention can be ordered when the person may flee (risk of absconsion) or he/she represents a threat to public order.

The practice of the Human Rights Committee and the case law of the European Court of Human Rights provide a noteworthy illustration of the conditions to be respected for detention to be lawful. $5^{8}$ In the case of the detention of aliens, for the detention not to be considered arbitrary certain requirements must be fulfilled: the detention can only last the time necessary to define the alien's status; the alien must be informed of the reason for the detention; access to legal advice, consular officers and relatives must be guaranteed, as well as access to judicial review. 59 These are the standards of non-arbitrariness which must be met in any case.

In the report drafted by the LIBE Committee, detention is allowed as a form of "control", in other words as a means of control over the undocumented migrants when there are grounds to suspect that they can constitute a security risk. In its final version, the Directive allows judicial or administrative detention which can be extended up to 18 months. In this way, the Directive opens the

Interamericano en la protección de los derechos de los migrantes', 24 Revista de derecho migratorio y extranjería, (20I0), 249274 .

57 Ibid, supra note 55 .

58 See Human Rights Committee A (Name deleted) v. Australia, 1997 and, also, CCPR, General Comment No. o8. Right to liberty and security of persons (Art. 9), 30/06/82; General Comment No. 15. The position of aliens under the Covenant, II/04/86. In the ECHR practice we can mention, for instance: Case Conka v. Belgium, ECHR (2002)App51564/99, RJD 2002-I, and Case Amuur v France, ECHR (1996) App no 19776/92, RJD 1996-III.

59 See U.N. Commission on Human Rights Working Group on Arbitrary Detention, Body of Principles for the Protection of All Persons under Any Form of Detention or Imprisonment regarding the situation of immigrants and asylum seekers. This body sets different principles: II. Guarantees Concerning Detention. Principle 6: The decision must be taken by a duly empowered authority with a sufficient level of responsibility and must be founded on criteria of legality established by the law. Principle 7: A maximum period should be set by law and the custody may in no case be unlimited or of excessive length. Principle 8: Notification of the custodial measure must be given in writing, in a language understood by the asylum-seeker or immigrant, stating the grounds for the measure; it shall set out the conditions under which the asylumseeker or immigrant must be able to apply for a remedy to a judicial authority, which shall decide promptly on the lawfulness of the measure and, where appropriate, order the release of the person concerned. Principle 9: Custody must be effected in a public establishment specifically intended for this purpose; when, for practical reasons, this is not the case, the asylum-seeker or immigrant must be placed in premises separate from those for persons imprisoned under criminal law. Principle Io: The Office of the United Nations High Commissioner for Refugees (UNHCR), the International Committee of the Red Cross (ICRC) and, where appropriate, duly authorized non-governmental organizations must be allowed access to the places of custody. U.N. Doc. E/CN.4/2000/4/Annex 2 (1999), available at http://wwwi.umn.edu/humanrts/instree/vsunchrad.html. 
possibility of the deprivation of freedom of migrants, even while their asylum applications or residence permits are being examined.

(iii) Expulsion measures involving a systematic ban on re-entry

Under the approved text, a ban from European territory for a maximum of 5 years can be issued together with every expulsion measure. ${ }^{60}$ The Parliament proposed that such a ban from the territory should not be made obligatory. ${ }^{6}$ In addition, the Parliament added the possibility of the ban being withdrawn or suspended for humanitarian or other reasons.

At present, this ban exists in some European countries. ${ }^{62}$ The main criticism is that the use of such a ban can lead to unacceptable situations, like not allowing people who have made a life in EU countries to return and try to resolve their legal situation, and pushing those who may want to return into illegality. Another weak point concerning this measure is that it would also have the effect of a double punishment, turning an undocumented migrant into a person guilty of an offence punished twice, by repatriating him/her and by forbidding him/her from returning. ${ }^{63}$

(iv) Mechanisms of protection and judicial review

With respect to the mechanisms for controlling the application of these measures, particularly the detention conditions, it must be underlined that detention in the Directive is called a "custody period." As mentioned above, when the detention is ordered by an administrative authority it has to be confirmed by a judicial authority "as speedily as possible." This expression is not auspicious. There is a lack of clarity and precision in the norm which may be problematic in the implementation of the Directive, mainly taking into account that, as stated before, the right of judicial review is a nonderogable right. General Comment 15 on the position of aliens under the Covenant states that "An alien must be given full facilities for pursuing his remedy against expulsion so that this right will in all the circumstances of his case be an effective one. The principles of article 13 relating to appeal against expulsion and the entitlement to review by a competent authority may only be departed from

60 Return Directive. Art. II.

6r The original text stated: Art. 9. Re-entry ban. I. Removal orders shall include a re-entry ban of a maximum of 5 years. Return decisions may include such a re-entry ban. 2. The length of the re-entry ban shall be determined with due regard to all relevant circumstances of the individual case, and in particular if the third-country national concerned: (a) is the subject of a removal order for the first time; (b) has already been the subject of more than one removal order; (c) entered the Member State during a re-entry ban; (d) constitutes a threat to public policy or public security. The re-entry ban may be issued for a period exceeding 5 years where the third country national concerned constitutes a serious threat to public policy or public security. 3. The re-entry ban may be withdrawn, in particular in cases in which the third-country national concerned: (a) is the subject of a return decision or a removal order for the first time; (b) has reported back to a consular post of a Member State; (c) has reimbursed all costs of his previous return procedure. 4. The re-entry ban may be suspended on an exceptional and temporary basis in appropriate individual cases. 5. Paragraphs I to 4 apply without prejudice to the right to seek asylum in one of the Member States.

62 Take for instance the cases of Spain and Germany.

${ }_{3}$ Another point which is not clear is the situation of individuals who received a ban on re-entry, and then due to a change in the conditions in the country of origin could eventually ask for refugee status. 
when "compelling reasons of national security" so require. Discrimination may not be made between different categories of aliens in the application of article $13 .{ }^{\prime \prime 4}$

The situation of undocumented migrants in Detention and Identification Centres (these functions may be alternative or cumulative) deserves particular attention. In recent years, Member States responsible for managing the entry of migrants travelling across land and sea routes into Europe (mainly Southern European countries) have been receiving funding from the European Union to build detention centres at their borders. On many occasions, the legal status of undocumented migrants remains unsolved for a long period with unacceptable periods of detention. Sometimes the whole identification process is difficult even if Member State governments are willing to solve it. In many cases, the undocumented migrant is unwilling to provide exact information about his or her State of origin. Different organizations working in the field (such as UNHCR, CIR (Consiglio Italiano per I rifugiati) and CEAR (Comisión Española de Ayuda al Refugiado) have warned about the side effect that this situation could generate: the creation of legal limbos. ${ }^{65}$ Even if the Directive were applicable in these Centres, it is not clear that it can bring a future improvement in the detention conditions reported.

(v) Emergency situations

A final controversial issue is that the Return Directive allows specific derogations on detention conditions in Member States that face so-called emergency situations. With regard to the actions to be adopted in the case of emergency situations, the flexibility allowed to the State generates concerns about the protection of human rights. Even if on the one hand it is true that massive migration (especially by sea) generates problems which are difficult to solve in practice, on the other hand, as human rights organizations have underlined, there is a risk that the application of these exceptional measures can lead to the derogation of basic human rights and fundamental freedoms.

\section{(e) The application of the I95I Geneva Convention on the Status of Refugees}

The 1951 Geneva Convention plays an important role in the context of return because of the principle of non refoulement. ${ }^{66}$ The application this principle implies the prohibition of the expulsion or forced return ("refoulement") of a refugee to a country "where his life or freedom would be threatened on account of his race, religion, nationality, membership of a particular social group or political opinion." ${ }^{67}$ This principle has been recognized at international and at regional level by different human rights instruments. ${ }^{68}$ As seen above, under the ECHR the principle does not admit exceptions

\footnotetext{
${ }^{6}$ General Comment No 15 . The position of aliens under the Covenant, available at http://wwwi.umn.edu/humanrts/gencomm/hrcomis.htm.

65 See, for instance, CEAR 2008 Annual Report, Section 9.

66 On this the protection of asylum seekers, see, among others, J. Hathaway, 'The rights of refugees under international law' (Cambridge University Press, Cambridge, 2005), 75-83 and 147-153, G.S. Goodwin-Gill, The Refugee in International Law (3 ed, Oxford, 2007) andG.S. Goodwin-Gill, 'The Dynamic of International Refugee Law', 25Int J Refugee Law (2013), 65I666.

${ }_{67}$ Art. 33, 1951 United Nations Convention Relating to the Status of Refugees.

68 The 1951 Geneva Convention and its 1967 Protocol have been reinforced by the adoption of other international instruments such as the Convention against Torture and Other Cruel, Inhuman or Degrading Treatment or Punishment
} 
on grounds of public order or national security, initially allowed by article 33 of the 195I Geneva Convention. ${ }^{69}$ At present, it can be said that there are grounds for considering the non refoulement principle part of customary international law..$^{\circ}$

In the context of immigration, the principle of non refoulement implies the immediate verification (before removal) of whether the individual has the right to file an application to determine refugee status or to apply for subsidiary protection. ${ }^{7 \mathrm{I}}$ While the principle has been enforced on state territory, its application at sea has become controversial. ${ }^{72}$

Interception on the high seas of potential undocumented migrants (the so-called boat people) raises a difficult question to answer. ${ }^{73}$ One possible solution would be the unrestricted application of the principle and the consequent obligation of the vessel which meets these people to take them to the State of its flag, or eventually to ask the coastal State for permission to disembark them for humanitarian reasons. ${ }^{74}$ In that case, disembarkation would, according to European law, determine the State in charge of examining eventual asylum claims. ${ }^{75}$ The second possibility would be that after checking the conditions and the respect of the essential human rights provisions and refugee law, individuals on board would be sent to a safe State. The third possibility would be to take them to centres created outside of the European borders and let human rights organizations contact them in order to grant them effective access to the procedure for determination of refugee status under the Refugee Convention or under other international protection. ${ }^{76}$ So far, the third solution has frequently been applied. Despite the Community legislation on asylum, international human rights

(1984), which provides in Art. 3.I that "No State Party shall expel, return ("refouler") or extradite a person to another State where there are substantial grounds for believing that he would be in danger of being subjected to torture." For the Americas, see the American Convention on Human Rights (1969), Art. 22.7/22.8 and 1984 Cartagena Declaration on the rights of refugees. For Africa, see the African Charter on Human and Peoples' Rights (198I) Art. I2 and I969 OAU Convention Governing the Specific Aspects of Refugee Problems, available at http://www.unhcr.org/45dcra682.html.

69 According to Lambert, "In the context of return, the Court further recognised the extraterritoriality effect of provisions of the ECHR, in particular Art. 3, when it held that a contracting party could be held responsible for treatment afforded to a person within a non-contracting party to the ECHR in the context of extradition (but also expulsion, deportation, etc.) procedures, Lambert, supra n. 18, at. 8. See Chahal vs. United Kingdom, supra n.29.

to Ibid. See also G. Goodwin-Gill, The refugee in international law, supra n. 66 and the UNHCR's submission to the European Court of Human Rights in the Case T.I. v. the United Kingdom, ECHR, admissibility decision of 7 March 2000.

${ }_{7} \quad$ See M. Foster, 'Protection Elsewhere: The Legal Implications of Requiring Refugees to Seek Protection in Another State', in 28 Michigan Journal of International Law (2007), 250-26r; and ECRE (European Council on Refugees and Exiles), 'Defending Refugees' Access to Protection in aurope', available http://www.ecre.org/component/downloads/downloads/6o.html.

72 See UNHCR, Advisory Opinion on the Extraterritorial Application of Non-Refoulement Obligations under the 195I Convention relating to the Status of Refugees and its 1967 Protocol, January 2007 and UNHCR, 'The protection of asylumseekers and refugees rescued at sea' in T. A. Aleinikoff and V. Chetail (eds) Migration and International Legal Norms (Asser Press; ist Edition. Edition, The Hague, 2003).

73 See N. Ronzitti, 'Coastal State Jurisdiction over Refugees and Migrants at Sea', in N. Ando et al. (eds), Liber Amicorum Judge Shigeru Oda (Kluwer Law Intemational, The Hague, 2002).

74 In this case, it is not always easy to obtain permission from the coastal State.

75 European Union: Council of the European Union, Council Regulation No. 343/2003 Establishing the Criteria and Mechanisms for Determining the Member State Responsible for Examining an Asylum Application Lodged in One of the Member States by a Third-Country National ("Dublin II"), 16 March 2003, No. 343/2003, available at http://www.unhcr.org/refworld/docid/3e5cfic24.html.

${ }_{76}$ See UNHCR, Refugee Protection and Mixed Migration: A io Point Plan of Action, January 2007. 
law and maritime law, the situation of boat people and access to asylum remain particularly difficult, since currently there is a lack of adequate standards applicable to the situation. ${ }^{77}$

With respect to the application of the 195I Geneva Convention, the Directive raises several questions. First of all, in the return procedure Member States must take account of the situation of the individual's country of origin before returning him or her, following the principle of nonrefoulement..$^{78}$ Secondly (as mentioned before), aside from the country of origin, the individual can be sent to a "country of transit in accordance with Community or bilateral readmission agreements or other arrangements, or another third country, to which the third-country national concerned voluntarily decides to return and in which he or she will be accepted" (Article 3.3). In these cases, there is no mention of the qualification of these other possible places of return. As can be seen, the question of where to return migrants is still quite controversial.

In the application of the Directive to cases where immigrants (including those arriving by sea) are intercepted at the border before entering the territory of the State, ${ }^{79}$ as seen before, Member States may decide to apply the provisions. Some scholars point out that such a distinction can lead to the creation of a different status of treatment for undocumented migrants, with cases in which the minimal safeguards are not applied..$^{80}$

The United Nations High Commission for Refugees (UNHCR) has recommended that the Directive's safeguards should be applied without distinction. The UNHCR's recommendations require the equal treatment of asylum-seekers intercepted at the border and those already on European territory, in order to put the Directive in line with the jurisprudence of the European Court of Human Rights. ${ }^{8 \mathrm{I}}$

\section{(f) The Return Directive and the 1989 Convention on the Rights of the Child}

With regard to the situation of children in general, and unaccompanied minors in particular, several points were raised during the negotiation of the Directive. ${ }^{82}$ Obviously, Member States have to respect the principle of the best interests of the child as established in the Convention on the rights of

77 See ASGI, 'Comments relating to the Green Paper on the future common European asylum system' (JLS/1977/o7EN), available at http://ec.europa.eu/dgs/home-affairs/what-is-new/publicconsultation/2007/pdf/contributions/ngo/asgi_associazione_studi_giuridici_sull_immigrazione_en.pdf.

${ }_{78}$ As Baldaccini points out, "following a recent ruling by the Court of Justice, the European Parliament will in the future decide jointly with the Council (under co-decision) which countries are deemed safe", supra n. 40 , at 6.

79 As for asylum seekers, the EU by means of the Schengen agreements (incorporated in the EU law as acquis Schengen), the Dublin Convention, different readmission agreements and a series of directives, has provided itself with a legal system guaranteeing a minimum standard of protection.

8o Baldaccini, supra n. 40, at 3 .

81 In particular see Case Ammuur v. France, 19776/92. UN High Commissioner for Refugees, 'UNHCR Position on the Proposal for a Directive on Common Standards and Procedures in Member States for Returning Illegally Staying ThirdCountry Nationals', I6 June 2008, available at http://www.unhcr.org/refworld/docid/4856322c2.html.

82 For an analysis of the Convention, see S. Dietrick, A Commentary on the United Nations Convention on the Rights of the Child (Martinus Nijhoff, Haag/Boston/London, 1999). On the question of migrant children J. Bhabha offers a complete examination of the international legislation in this matter, see in T. A. Aleinikoff and V. Chetail (eds) Migration and International Legal Norms (Asser Press; Ist Edition. Edition, The Hague, 2003), Chapter I2 - Children, migration and international norms, at 203-223. 
the Child. ${ }^{83}$ The Directive foresees certain extra guarantees when the person to be removed is a child, for instance to provide him/her with proper conditions of accommodation, quite a difficult question as can be appreciated in the ruling of the ECHR in the case Mubilanzila Mayeka and Kaniki Mitunga $v$. Belgium. ${ }^{84}$ The most controversial questions in this respect regard the concrete application of the principle to cases of the return of children and the situation of separated children. ${ }^{85}$

In practice, it is difficult to assess the application of the principle of the best interest of the child in each Member State, because some of them make a narrow interpretation of this principle in the immigration context. In this aspect, the suggestion of specialized NGOs was to follow the experience of certain States and ask the Commission to provide Member States with guidelines to assist them in the implementation of this key principle. ${ }^{86}$

In the case of separated children, ${ }^{87}$ the determination of their best interests is even more complex because there are many elements to be taken into account. Therefore, Member States "should assess and balance a variety of factors including: safety, family reunification, the child's view, voluntary return, age and maturity of the child, child's level of integration in the host country, socio-economic conditions in the country of origin and the views of the legal guardian and carer." 88

Another provision of the Directive to be examined is article 5, concerning family relationships and the best interest of the child. Even though the Directive expressly mentions that Member States "shall take due account of the nature and solidity of the third-country national's family relationships," there is no concrete reference to respect for family unity. During the negotiation of the Directive, it was recommended that it should be "clearly stated that children should never be separated from their families or primary caregivers unless this is in the child's best interests." ${ }_{9}$

83 Adopted and opened for signature, ratification and accession by General Assembly resolution 44/25 of 20 November 1989. The Convention entered into force on 2 September 1990. In Art. 3, the Convention states: "I. In all actions concerning children, whether undertaken by public or private social welfare institutions, courts of law, administrative authorities or legislative bodies, the best interests of the child shall be a primary consideration".

${ }^{84}$ Case of Mubilanzila Mayeka and Kaniki Mitunga v. Belgium (Application no. $13178 / 03$ ), $2^{\text {th }}$ October 2006. The case is available at http://www.unhcr.org/refworld/pdfid/45d5cef72.pdf.

85 Different stakeholders (mainly organizations) who are working for the protection of Children issued reports and position papers with respect to the Return Directive. See, for instance, Save the Children, 'Comparative Study onPractices in the Field of Return of Minors' (20II) available athttp://ec.europa.eu/homeaffairs/doc_centre/immigration/docs/studies/Return_of_children-final.pdf.

${ }_{86}$ Take as an example the case of Sweden, where the Ombudsman for Children issued a report on how the best interests principle should be applied to asylum applications and listed the following criteria for assessing a child's best interests: the child's need to be with its parents; the child's need for health care including medical care and rehabilitation; the child's relationship to its parents. See ECRE,' Comments on Proposal for a Directive of the European Parliament and of the Council on common standards and procedures in Member States for returning illegally staying third-country nationals' (2006) at II, available at http://www.ecre.org/component/downloads/downloads/86.html.

${ }_{7}$ "Separate children" means children under I8 year of age who are outside their country of origin and separated from either parents or their previous legal/customary primary caregiver. See also the report of the Committee for the Rights of the Child, CRC General Comment No. 6 (2005) on Treatment of Unaccompanied and Separated Children, available at http://www2.ohchr.org/english/bodies/crc/docs/GC6.pdf.

88 See ECRE,' Comments on Proposal for a Directive of the European Parliament and of the Council on common standards and procedures in Member States for returning illegally staying third-country nationals', supra n. 86.

89 According to the ECRE report, families with children should not be forcibly removed if it is in the child's best interests to stay. See supra n. 86. 
It is notable that Article 8 of the Directive includes the postponement of removal in the case of unaccompanied minors who are pending an assessment in their country of origin and arrangements for handover of their care. $9^{\circ}$ Even this special consideration given to unaccompanied minors still needs more clarification. In fact, it would have been appropriate to cover a variety of aspects, such as child welfare and security concerns, and most importantly the necessity of consulting the child regarding the decision..$^{\text {I }}$

Finally, it should be noted that initially there was a proposal to include in the Directive the possibility of Member States granting an "autonomous resident permit" for children, based on humanitarian reasons following the example of other cases already foreseen in EU legislation. ${ }^{92}$

As can be appreciated, with regard to the application of the Convention on the Rights of the Child, the main issue, clearly, is to make sure that the principle of the best interests of the child applies as a primary consideration in every case in which a child is involved in the immigration context. In order to guarantee the application of this in practice, it would be appropriate for the Commission to draw up accurate guidelines, or a collection of best practices. In this way, a further level of protection can be granted to children, especially during the expulsion procedure.

\section{(2) Assessing the implementation of the Return Directive}

Having considered the whole scenario of the Directive, the question then arises as to how the Directive has been implemented in the years after the adoption. As in other cases, EU countries were supposed to internalize the Directive by the means they consider most appropriate. ${ }^{93}$

Consequently, the Directive was transposed in different manners. Taking as an example the case of Spain, further modifications to the 2000 Immigration Act (Ley Orgánica de Extranjería) were introduced in 2009 in order to adapt it to EU legislation on immigration, including the Return

90 Return Directive. Art. 8. Postponement. I. Member States may postpone the enforcement of a return decision for an appropriate period, taking into account the specific circumstances of the individual case. 2. Member States shall postpone the execution of a removal order in the following circumstances, for as long as those circumstances prevail: (a) inability of the third-country national to travel or to be transported to the country of return due to his or her physical state or mental capacity; (b) technical reasons, such as lack of transport capacity or other difficulties making it impossible to enforce the removal in a humane manner and with full respect for the third-country national's fundamental rights and dignity; (c) lack of assurance that unaccompanied minors can be handed over at the point of departure or upon arrival to a family member, an equivalent representative, a guardian of the minor or a competent official of the country of return, following an assessment of the conditions to which the minor will be returned. 3. If enforcement of a return decision or execution of a removal order is postponed as provided for in paragraphs I and 2, certain obligations may be imposed on the third country national concerned, with a view to avoiding the risk of absconding, such as regular reporting to the authorities, deposit of a financial guarantee, submission of documents or the obligation to stay at a certain place.

${ }_{91}$ It is relevant to underline that recently the Committee on the Rights of the Child has issued a comment which provides guidance on this matter and it should be applied in these cases. See CRC General Comment No. 6 (2005) on Treatment of Unaccompanied and Separated Children.See supra n. 87.

92 See, for instance, the Council Directive 2004/8I/EC of 29 April 2004 on the residence permit issued to third-country nationals who are victims of trafficking in human beings or who have been the subject of an action to facilitate illegal immigration, who cooperate with the competent authorities, EU Directive 2004/8I on residence permits to victims of trafficking, available at http://eur-lex.europa.eu/LexUriServ/LexUriServ.do?uri=CELEX:32004Loo8r:EN:NOT.

93 The deadline for the implementation was $24^{\text {th }}$ December 20Io. The United Kingdom and Ireland opted out of this part of EU Law and therefore they shall not be obliged to fulfil the Directive. 
Directive. ${ }^{4}$ Italy did not pass any new modification within the deadline. However, Italian authorities transposed the directive after the State was condemned in 2010 by the Court of Justice of the EU (El Dridi case) on the grounds that some of its legal procedures (specially the long period of imprisonment as punishment for refusing to leave the country after receiving a deportation order) were in conflict with the Return Directive. ${ }^{95}$

A comparative study released in 2014 based on fieldwork carried out in Italy, Spain and Cyrpus has revealed that, in practice, the effective enforcement of the Directive has hardened the conditions imposed on undocumented migrants. ${ }^{96}$ At the same time, the EU Fundamental Rights Agency and the Council of Europe have emphasized the need for the State authorities to comply with minimum procedural guarantees (such as providing legal assistance to the concerned immigrants) and respect human rights when carrying out removals (they must be safe, dignified and humane). ${ }^{97}$

Not surprisingly, various cases addressing the implementation of the Directive have come to the public domain since $201 \mathrm{I} .{ }^{98}$ Clearly, after El Dridi $\mathrm{V}$ Italy (20II) other several cases on the implementation of the Directive have emerged in the jurisprudence of the CJEU.99 Indeed, "El Dridi" case inaugurated a "new era" in the CJEU case law. ${ }^{100}$

After that case, similar claims were brought before the CJEU. In all these recent cases, the CJEU had the opportunity to address the implementation of the Directive. In the first two judgements, the Court intervened and set forth criteria in order to scrutinise the enforcement of the Directive. In the notorious case El Dridi, the Court examined the admissibility of criminalizing the non-compliance of a repatriation order following a period for voluntary departure. ${ }^{\text {IOI }}$ In its judgement, the Court recalled that in principle Member States are allowed to adopt measures - including criminal law measures to avoid the irregular stay of third-country nationals in their respective countries. However, the

942000 Immigration Act (Ley Orgánica 4/2000, del II de enero, sobre Derechos y Libertades de los Extranjeros en España y su Integración Social). The reform proposed was approved by the executive branch on $26^{\text {th }}$ June 2009 and was passed as $\mathrm{LO}_{2} / 2009$ on II December 2009. On the Spanish immigration legislation, see P. González Saquero, 'La Directiva "retorno"y el alcance de la armonización del procedimiento de expulsión de extranjeros (Sentencia del TJUE de 28.4.20II, as. El Dridi C-6I/II)', 6 WP IDEIR (20II) and C. Gortázar, 'Spain: Two Immigration Acts at the End of the Millennium', 4European Journal of Migration and Law (2002) I-2I. See supra n. 25.

95 See F. Bertin, E. Fontanari and L. Gennari, 'At the Limen. The implementation of the return directive in Italy, Cyprus and Spain', (2014). Available at http://www.borderline-europe.de/sites/default/files/background/20r4_Final_brochure_at-thelimen.pdf.

96 Ibid.

${ }_{97}$ Council of Europe and European Union Agency for Fundamental Rights, Handbook on European law relating to asylum, borders and immigration, January 20I4. Available at http://www.echr.coe.int/Documents/Handbook_asylum_ENG.pdf .

${ }_{98}$ See, for instance, the following cases: Case C-473/13, Bero e.a. [2014] (not yet published in the ECR); Case CI46/I4/PPU,Mahdi [2014] (not yet published in the ECR); Case C-I66/I3, Mukarubega [2014] (not yet published in the ECR); Case C-474/I3; Pham [2014] (not yet published in the ECR); Case C-394/12; Abdullahi [2013] (not yet published in the ECR);Case C-297/I2, Filev \& Osmani [2013] (not yet published in the ECR); Case C-329/II, Achughbabian [201I] I-I2695. A complete and updated list of the CJEU case law on immigration is available at http://europeanmigrationlaw.eu/en/jurisprudence_cjue\#immigration_99_4_o.

99 Case C-6I/II, El Dridi, ruling delivered on $28^{\text {th }}$ April 20II, supra n. 25.

roo See J. J. Martín Arribas, 'Reflexiones sobre los derechos de los inmigrantes en situación irregular según el derecho de la Unión Europea', 32 Revista de derecho migratorio y extranjería, (2013) II-53.

ror Case C-6I/II, El Dridi, supra n. 25 . 
Court specified that although criminal law falls into the responsibility of each Member State, this particular branch could be subordinated to European Union law. As a result "States may not apply rules, even criminal law rules, which may jeopardize the achievement of the objectives pursued by the directive, depriving it of its effectiveness". ${ }^{102}$ Therefore, the Court established the need to balance Member States' power in matters regarding undocumented third-country nationals under deportation orders with and the need safeguard "the effet utile of the directive".

In a similar case, the Achoughbabian judgement decided in December 20II, the Court reasserted the findings of the El Dridi judgement. ${ }^{103}$ Indeed, the CJEU confirmed that the Return Directive 2008/IIs does not preclude penal sanctions in line with national criminal legal procedure with regards to undocumented third-country nationals who are residing in the territory of a member state without any justified grounds for non-return (par. 48). ${ }^{104}$ However, penal sanctions could only be applied if the return procedure has already been requested.

In other further cases related to the compatibility of national legislation imposing certain penal sanctions (assignment to stay at home; immediate expulsion) for illegal staying with the Return Directive $^{\text {Ios }}$ and related to domestic law provisions criminalizing non-compliance with an entry ban, the Court has reaffirmed these previous criteria. ${ }^{106}$ In the case Sophie Mukarubega $v$ Préfet de police, decided on 5 November 20I4, the CJEU upheld right to be heard before the return decision is issued relaying upon previously settled cases dealing with the Return Directive (El Dridi, C-6I/II, Arslan C534/II and Pham). ${ }^{107}$ In particular, the Court underlined: "The right to be heard in all proceedings is now affirmed not only in Articles 47 and 48 of the Charter, which ensure respect for both the rights of the defence and the right to fair legal process in all judicial proceedings, but also in Article 4I of the Charter, which guarantees the right to good administration. Article $4 \mathrm{I}(2)$ of the Charter provides that the right to good administration includes, inter alia, the right of every person to be heard before any individual measure which would affect him adversely is taken". ${ }^{108}$ The Court went on to clarify that "Consequently, the obligation to adopt, with respect to third country nationals who are staying illegally in their territory, a return decision, laid down by Article 6(I) of the directive, within a fair and transparent procedure, entails that Member States must, within the context of their procedural autonomy, first, explicitly make provision in their national law for the obligation to leave the national territory in cases of illegal stay and, second, ensure that the person concerned is properly heard within the procedure relating to his residence application or, as the case may be, on the legality of his stay". ${ }^{\circ}$

I02 Ibid, par. 55 .

ro3 Case C-329/II, Achughbabian [2011] I-I2695 (France).

${ }^{104}$ R. Raffaelli, 'Case note: the Achoughbabian case. Impact of the return directive on national criminal legislation', Diritto Penale Contemporaneo, 2012. Available at http://www.penalecontemporaneo.it/upload/Nota\%20En\%20Achughbabian.pdf.

ros Case C-430/II, Sagor [20I2] ECR 777 regarding the compatibility of Italian law with the Directive.

ro6 Case C-297/I2, Filev and Osmani [2013] supra n. 98 (Germany).

ro7 Case C-I66/I3, Case C-I66/I3, Mukarubega [2014] supra n. 98, Request for a preliminary ruling (France).

108 Ibid, par. 43 .

109 Ibid, par. 62. In light of the circumstances of the case, the Court concluded that the right to be heard had been respected. 
It should be noted that, as anticipated by previous NGOs reports, cases of return of immigrants involving the protection of children's rights have also arisen. Different cases were heard before the European Court of Human Rights, concerning the return of third-country nationals including children such as Anayo and Saleck Bardi. ${ }^{\text {Iro }}$ In both cases, the European Court of Human Rights concluded that there was a violation of Article 8 of the ECHR since there were flaws in the decisionmaking process, in particular, the failure to protect the "welfare principle", the lack of consideration if the best interests of the child and a deficient coordination between the authorities in determining and protecting such interests.

To conclude, the Return Directive is posing continuous challenges to EU immigration system in particular. Taking into consideration the manner in which it is implemented in the different EU Member States, different controversial situations for the respect of human rights arise. Despite the "good intentions" aimed at in its adoption, as the recent case law appears to suggest, when Member States are faced with the conflict the equation is not always favourable to the compliance with human rights obligations imposed by regional European law and customary international law.

\section{THE RETURN POLICY AND THE IMPACT ON THE RELATIONS WITH IMMIGRANTS' COUNTRIES OF ORIGIN: ITALIAN AND SPANISH PRACTICES}

As for the effect of the Directive on the countries of origin of the immigrants, by impact in this article we mean, primarily, the possible consequences of the Return Directive on cooperation with the immigrants' countries of origin, in particular taking into account the conclusion of agreements with these countries. ${ }^{\text {III }}$

In recent years, the joint management of migration flows and cooperation with third countries have been at the top of the EU migration agenda. Following a series of European Council decisions, migration and border management became part of the external dimension of the Area of Freedom, Security and Justice (AFSJ). ${ }^{\mathrm{II}}$ In particular, since the Tampere European Council and the entry into force of the Amsterdam Treaty, ${ }^{\mathrm{II}}$ this area has been increasing in importance and several actions have been included within the European Neighbouring Policy (ENP). ${ }^{\text {I4 } 4}$ Indeed, many readmission clauses have been negotiated (for instance in the Cotonú Agreement with ACP countries) and various

ro ECHR, Anayo v. Germany, No. 20578/07, 21 December 20I0; ECHR, Saleck Bardi v. Spain, No. 66167/09, 24 May 2011.

III Another significant aspect to take into account is the financial one. At EU level, the Commission has proposed the establishment of a European Return Fund for the period 2008-2013 as part of the general programme: "Solidarity and Management of Migration Flows.”

II2 See N. Walker (ed) Europe's Area of Freedom, Security and Justice, Volume XIII/2 of The Collected Courses of the Academy of European Law, chapter 3 (Oxford University Press, Oxford, 2004) at 89-I42.

"I3 The Amsterdam Treaty gave the EC the competence to take "measures on immigration policy ... in the area of illegal immigration and illegal residence, including repatriation of illegal residents".

I14 See M. Cremona, 'EU External Action in the JHA Domain: A Legal Perspective', EUI Working Papers LAW 2008/24, available at http://cadmus.eui.eu/bitstream/handle/I8I4/9487/LAW_2008_24.pdf?sequence=I. See, also, J. Rijpma and M. Cremona, 'The Extra-Territorialisation of EU Migration Policies and the Rule of Law', EUI Working Papers, Law 2007/or, European University Institute, Italy, available athttp://cadmus.eui.eu/bitstream/handle/I8I4/6690/LAW_2007_or.pdf?sequence=I. 
readmission agreements have been signed both by the EU and its Member States. ${ }^{\text {II }}$ Therefore, in the latter case, third countries (countries of origin or of transit of immigrants) which make formal agreements with the EU or a Member State undertake various legal commitments in managing migration flows. These bilateral or multilateral readmission agreements, in essence, "impose reciprocal obligations on the contracting parties to readmit their nationals, and set out technical and operational criteria for this process." ${ }^{116}$ These agreements cover nationals of the contracting parties, but also nonnationals, a category which encompasses stateless persons and persons who are neither citizens of the EU nor of the other contracting party. ${ }^{\mathrm{II}}$

In the 2000's, the EU practice of including readmission clauses in agreements became a general requirement for all EU external agreements and there was a profusion of readmission agreements concluded by the EU. At the same time, EU Member States continued to sign bilateral readmission agreements with third countries. ${ }^{\mathrm{II} 8}$

The initial approach taken by the EU in terms of readmission has been criticized because it only focused on preventive measures and it did not include any kind of activities to protect the fundamental human rights of the irregular migrants themselves. In response to those criticisms, a new approach was adopted enhancing co-operation with the third countries and emphasizing "shared responsibility," "shared values" and "joint ownership and co-responsibility."

In recent years, a move from the traditional view of the management of migration flows focusing only on police control, towards a new point of view focused on cooperation with third countries involved in a broad sense can be observed. As C. Boswell states, "EU states have increasingly sought to address migration management dilemmas through cooperation with migrant-sending countries and the 'transit' countries through which migrants and refugees travel." 20

A further differentiation can be made in this external dimension of EU cooperation in justice and home affairs related to cooperation with third countries (sending and transit countries). In fact, EU cooperation with third countries over immigration covers two different approaches in terms of policy: ${ }^{121}$

- The "Traditional approach:" This first approach focuses on controlling irregular immigration flows with various legal tools. C. Boswell defines it by saying that "the logic here is to engage sending and transit countries in strengthening border controls, combating illegal entry, migrant

\footnotetext{
is See Ch. Boswell, 'The 'External Dimension' of EU Immigration and Asylum Policy', 79 International Affairs (2003) 619-638.

II6 See A. Roig, T. Huddleston, 'EC Readmission Agreements: A Re-evaluation of the Political Impasse', 9 European Journal of Migration and Law(2007) 363-387 at 363.

${ }^{117}$ Ibid, at 364.

II It should be pointed out that even though it is not a direct competence of Frontex, this Agency has been facilitating the conclusion of different working agreements between Member States and third countries under Art. I4 of Regulation No. 2007/2005 which established Frontex. In addition, other operations have been launched within the EU framework: RABIT (Rapid Border Intervention Teams); SAR (Search and Rescue) and SOLAS (Safety of Life at Sea).

II9 See J.P. Cassarino, 'The EU Return Policy: Premises and Implications', supra n. 8.

I20 See C. Boswell, supra n. II5.

${ }^{122}$ Ibid.
} 
smuggling and trafficking, or readmitting migrants who have crossed into the EU illegally." ${ }^{22}$

- The "Preventive approach:" This second approach embraces measures aimed at changing the situation in the countries of origin and transit of immigrants. These measures can include "a rather different range of tools to increase the choices of potential refugees or migrants: development assistance, trade and foreign direct investment, or foreign policy tools." ${ }^{23}$

As will be noticed, the new EU strategy in this field seeks to include not only the first approach but also the second as essential. Recalling The Hague Programme, the current strategy "calls for genuine partnership with the third countries concerned and must be fully integrated with the Union's other external policies." ${ }^{24}$ Besides, in its Communication on migration and development (adopted in 2005), the Commission underlined the positive impact of the return of immigrants to their countries of origin $^{\mathrm{I} 25}$ in order to highlight that one of the main aims is the establishment of partnerships with sending countries, emphasising the link between migration and development. In this line, a joint strategy between the EU and African countries has been adopted in recent years. ${ }^{\mathrm{I} 2}$

Having broadly considered the main aspects of EU external relations concerning migration issues, we can now examine the different positions held with regard to the Directive, the focus here will be placed on two specific countries: Italy and Spain. ${ }^{27}$ In both, non-EU migration has increased over the past ten years. In order to address the question, the measures included in the agreements will be analysed. ${ }^{128}$

Italy and Spain, as Mediterranean countries, have faced considerable immigration pressure over recent years since they are countries of entry, transit or destination for many illegal immigrants. Both countries have signed various readmission agreements. These agreements include individuals who hold the nationality of the contracting parties as well as illegal third-party nationals and stateless persons. The countries of transit were reluctant to cover these third-party nationals, in particular, during the implementation of the agreements. The case of Moroccan and sub-Saharan African people intercepted when attempting to enter into Spain illustrates this difficulty in the execution of these agreements very well. ${ }^{\mathrm{I} 9}$ Within this general framework, however, it must be acknowledged that there are differences in the cases selected.

I22 Ibid.

I23 Ibid.

${ }^{124}$ The Hague Programme, supra n. 3.

${ }^{125}$ See Communication from the Commission to the Council, the European Parliament, the European Economic and Social Committee and the Committee of the Regions, Migration and Development: Some concrete orientations, (COM(2005) 390 final), Brussels, or.09.2005, available at http://eur-lex.europa.eu/legal-content/EN/ALL/?uri=CELEX:52005DC0390.

${ }^{226}$ See Joint Africa-EU Declaration on Migration and Development (Tripoli, 22-23 November 2006), EU-Africa Summit, Lisbon, 7-9 December 2007 and Africa-EU Strategic Partnership, available at https://www.iom.int/jahia/webdav/shared/shared/mainsite/microsites/rcps/igad/african_md_declaration_2006.pdf.

${ }^{127}$ M.B. Olmos Giupponi, 'Competencias regionales y política de inmigración en Europa: el caso de España e Italia', 59 Cuadernos de Federalismo:Federalismo Comparado, Academia Nacional de Derecho y Ciencias Sociales, Córdoba, Argentina (2009) $245-275$.

${ }_{128}$ EU Triton Operation in Italy was launched on 3r October 2014 with the aim of securing the borders and, only in case of necessity, rescuing immigrants from the sea.

${ }^{129}$ As an additional difficulty, the construction of shape-topped walls in Melilla and Ceuta has raised several human rights concerns. Some cases are known as "devoluciones en caliente", i.e. foreigners are expelled even before legally entering 


\section{(I) Italian practice}

As mentioned above, the Return Directive was not implemented in Italy by the deadline. ${ }^{130}$ Only after the Case El Dridi ${ }^{131}$, the State decided to pass the d.1. 89 of 23 th June 20II, later converted to 1.n. I29/20II to adapt the previous immigration legislation to the Return Directive. ${ }^{\mathrm{I} 2}$

In the case of Italy, the Return Directive has clear implications for its relationship with Libya. ${ }^{133}$ It is worth noting that Libya is not itself a country of emigration but rather a country of transit for many immigrants from Sub-Saharan Africa (Sudan, Chad, and Niger), a region with high poverty rates and several armed conflicts. ${ }^{34}$ Another important immigration flow comes from the region known as the Horn of Africa (Eritrea, Ethiopia and Somalia), also devastated by conflicts and hunger. ${ }^{\mathrm{I} 5}$ In addition to the different bilateral agreements on the management of migration flows, a new framework agreement between Italy and Libya was signed in $2008 .^{136} \mathrm{In}$ this agreement, the Italian government showed its commitment to the local development of the country. ${ }^{137}$

Spanish jurisdictions without contemplating the possibility of seeking asylum (in contradiction with the non-refoulement principle and some provisions of the Return Directive and other international human rights norms). In November 20I4, the Rapporteur for migrants' rights, François Crépeau has called on Spanish authorities in order not to pass the bill legalizing these devolutions. See M. Martinez Escamilla et al, 'Expulsiones en caliente: cuando el Estado actúa al margen de la Ley', Universidad Complutense de Madrid, 20I4, available elctronically at $<$ http://eprints.ucm.es/25993/I/INFORME\%20\%20EXPULSIONES\%20EN\%20CALIENTE.\%2027_6_2014\%20\%281\%29. pdf $>$.

${ }_{\text {ro }}$ See A. Calamia, M. Di Filippo \& M. Gestri (ed), Immigrazione, Diritto e Diritti: profili internazionalistici ed europei (CEDAM, Padoa, 20I2).

${ }_{331}$ See R. Raffaelli, 'The returns directive in light of the El Dridi judgment', ${ }_{3}$ Perspectives on Federalism (2011) 32-45.

${ }_{132}$ See F. Bertin, E. Fontanari and L. Gennari, 'At the Limen. The implementation of the return directive in Italy, Cyprus and Spain', supra n. 95 .

${ }_{133}$ With regard to the internal legal framework in Italy, in 1998, Law No. 40/1998, also known as the "Turco-Napolitano Law" was passed (later confirmed by Single Act no. 286 of July 25, 1998), regulating on entry, residence and working conditions, to that of deportations and control of the illegal phenomenon. Apart from a new emphasis on the need to regulate undocumented immigration, the main innovation was an effective introduction of a "programmed entries" system of foreign workers via quotas on a yearly basis. In 2002 the previous legislation was modified by the "Bossi-Fini Law" (no.189/2002).

${ }^{134}$ On the different migration flows to Italy and illegal immigration see F. Fasani, 'Undocumented Migration - Counting the Uncountable. Data and Trends across Europe', Country report: Italy, November 2008 (revised August 2009), available athttp://irregular-

migration.net/typo3_upload/groups/3I/4.Background_Information/4.4.Country_Reports/Italy_CountryReport_Clandestino _Novo9_2.pdf.

${ }_{335}$ F. Pastore, 'Migrazioni e relazioni Italo-Libiche - Come uscire da questa impasse', 25 June 2008, CESPI Policy Paper, available at http://www.cespi.it/PDF/Pastore-Tripoli\%2or8-6-o8_.pdf.In this paper F. Pastore argues that Libya can be considered at this time an immigration country due to the reception of regional migration flows.

${ }^{136}$ See Agreement between Italy and Libya (Trattato di amicizia, partenariato e cooperazione tra la Repubblica italiana e la grande Giamahiria araba libica popolare socialista), 23 December 2008, available at http://www.camera.it/_dati/legi6/lavori/schedela/apriTelecomando_wai.asp?codice=16PDLoor7390. From 2000 to date several agreements on the control of illegal immigration have been signed. The last of them (Accordo tra Italia e Libia per il contrasto all'immigrazione clandestina) was signed on $29^{\text {th }}$ December 2007 in Tripoli by the Minister of Internal Affairs Giuliano Amato and the Lybian Foreign Affairs Minister, Abdurraham Mohamed Shalgam. Later on, in February 2008, the Italian Minister of Internal Affairs back then, Roberto Maroni, adopted an additional agreement jointly with the Libyan authorities.

${ }^{137}$ On Italian policy on migration, see, amongst others, F. Pastore, 'La politica migratoria', in R. Aliboni, F. Bruni, A. Colombo, E. Greco (ed), L'Italia e la politica internazionale (Il Mulino, Bologna, 2000); and by the same author, 'La politica dell'immigrazione', in F. Bruni, N. Ronzitti (ed), L'Italia e la politica internazionale (Il Mulino, Bologna, 20oI). 
As has been shown before, EU migration and asylum policy is built on both EU competences and those of Member States. ${ }^{138}$ Thus, the measures adopted in many cases depend on the single Member State. In the case of the Agreement between Italy and Libya, ${ }^{139}$ the key issues are:

- Legal framework: As legal framework, the contracting parties acknowledge the prevalence of the United Nations system. They agree on the respect of the traditional principles laid down by the United Nations relating to the relationship between different States, such as equality of the sovereignty of member States.

- Respect for buman rights: Both parties recognize the importance of respect for fundamental human rights and fundamental freedom, as well as the relevance of inter-cultural dialogue. ${ }^{140}$

- Measures to be taken to fight against irregular immigration: With regard to measures to be taken to fight against irregular immigration, the treaty underlines that both parties have to develop stronger cooperation in this field. ${ }^{14 \mathrm{I}}$ In particular, Italy and Libya make the commitment to intensify their cooperation in fighting against terrorism, organized crime (...) and irregular immigration. In this regard, it is important to point out that there is a specific agreement which was signed in Rome in 2000, and several reports in this field, as well as specific Cooperation Protocols concerning irregular immigration signed in Tripoli in 2007.

Furthermore, and with regard to the fight against irregular migration, the contracting parties agree on:

- The implementation of a system to control the Libyan borders, to be built with the aid of Italy and the European Union;

- The definition of new bilateral and regional initiatives to prevent the phenomenon of irregular immigration in the countries of origin of the migratory flows.

As can be observed, in the partnership between Italy and Libya, the fights against human trafficking and smuggling at sea take a central role. The main question concerns undocumented migrants who arrive en masse in Sicily (Lampedusa Island), ${ }^{142}$ where there is a centre to identify and return them (Centro di identificazione ed espulsione). The controversial issue is the role of Libya in the management of immigration flows, since this country is also involved in the process of identification

${ }^{13} 8$ On the situation of the Mediterranean Sea, see D. Lutterbeck, 'Coping with Europe's Boat People. Trends and Policy Dilemmas in Controlling the EU's Mediterranean Borders', ISPI Policy Brief No. 76, February 2008, available athttp://www.ispionline.it/it/documents/PB_76_2008.pdf.

139 Trattato di amicizia, partenariato e cooperazione tra la Repubblica italiana e la grande Giamahiria araba libica popolare socialista, supra n. 136 .

${ }^{140}$ Ibid. Art. 6. Rispetto dei diritti umani e delle libertà fondamentali. Le Parti, di comune accordo, agiscono conformemente alle rispettive legislazioni, agli obiettivi e ai principi della Carta delle Nazioni Unite e della Dichiarazione Universale dei Diritti dell'Uomo. Articolo 7. Dialogo e comprensione tra culture e civiltà. Le Parti adottano tutte le iniziative che consentano di disporre di uno spazio culturale comune, ispirandosi ai loro legami storici ed umani. Le iniziative suddette si ispirano ai principi della tolleranza, della coesistenza e del rispetto reciproco, della valorizzazione e dell'arricchimento del patrimonio comune materiale e immateriale nel contesto bilaterale e regionale.

I4r Ibid. Art. I9.

${ }^{142}$ Statistical data on the number of undocumented migrants arriving in Lampedusa processed by CESPI on the basis of the information provided by the Internal Affairs Ministry are available at http://www.cespi.it. 
and return of the undocumented migrants. ${ }^{\mathrm{I} 3}$ The recent implementation of the framework agreement and the bilateral agreements on immigration has caused several reactions. The United Nations High Commissioner for Refugees, the Italian Council for Refugees (Consiglio Italiano per I Rifugiati) and human rights NGOs have expressed their concern about the restrictive application of the nonrefoulement principle after the signature of the agreements, mainly because Libya is not party to the 195I Geneva Convention. ${ }^{144}$ Furthermore, in 2005 some cases on the return of immigrants towards Libya reached the Strasbourg Court, which adopted an urgent provision suspending the removal of some of them. ${ }^{145}$

As can be appreciated, the issue is highly controversial. As a matter of principle, the agreement stipulating migration controls away from the borders should reconcile the activities foreseen with the protection of basic human rights, such as the right to apply for refugee status or other kinds of international protection and the possibility of judicial review. ${ }^{\mathrm{I} 6}$ Consequently, the implementation of a cooperation agreement in the context of undocumented migration should include measures to undergo a preliminary verification of the risk individuals might be at in their country of origin. ${ }^{147}$

The current migratory situation is difficult to handle; however, depending on political willingness it could be improved. ${ }^{.48}$ On the one hand, it should be pointed out that at EU level, Directive 2008/II5 enhances the cooperation between Member States and the countries of origin and transit of immigrants. The initial budget for the implementation of the Directive includes the monitoring of the Libyan border and the realization of other supportive measures. ${ }^{\text {I49 }}$ On the other hand, the change in the conception of the bilateral relationships between Italy and Libya reinforcing the construction of an effective partnership focuses on the stabilization and the development of the North-African countries as a means of managing immigration and guaranteeing respect for human rights. ${ }^{150}$

${ }^{143}$ On immigration by sea, among others see T. Scovazzi, 'La lotta all'immigrazione clandestina alla luce del diritto internazionale del mare', in 4 Diritto, immigrazione e cittadinanza (2003) 48-60; United Nations Office on Drugs and Crime, Organized Crime and Irregular Migration from Africa to Europe, July 2006 available at http://www.unodc.org/pdf/research/Migration_Africa.pdf; L. Coslovi, 'Brevi note sull'immigrazione via mare in Italia e Spagna', January 2007, available at http://www.cespi.it/PDF/mig-mare.pdf.

${ }_{144}$ See ASGI, Accordo Italia Libia sui migranti - Estrema preoccupazione per l'annunciato accordo italo-libico espressa dall'Associaizone Studi Giuridici sull'Immigrazione, 3r December 2007; Amnesty International, Visita del capo di stato libico Muhammar Gheddafi: la Sezione Italiana di Amnesty International chiede all'Italia di porre fine a una cooperazione priva di garanzie in materia di diritti umani, Rome, 09/06/2009; EL PAIS, 'La ONU critica a Italia por expulsar a Libia a inmigrantes 'sin papeles", Rome, 16/07/2009.

I45 See A. Gagliardi, 'La Corte di Strasburgo boccia l'Italia: sospese II espulsioni in Libia”, I4 June 2005, , available at http://www.libertysecurity.org/article284.html.

I46 See J. Rijpma and M. Cremona 2007, supra n. II4.

${ }^{147}$ See R.L. Newmark, 'Non-refoulement run afoul: The questionable legality of extraterritorial repatriation programs', 7I Washington University Law Quarterly (1993) 833-845.

${ }_{148}$ For an analysis of the development of Italian practice see A. Baldaccini, 'The EU directive on return: principles and protests', 28Refugee Survey Quarterly (2010); G. Bronzini, 'The "Return” Directive: European Values at Risk', 3 The federalist debate (2008); M. Borraccetti,' Il rimpatrio di cittadini irregolari: armonizzazione (blanda) con attenzione (scarsa) ai diritti delle persone', IDiritto, Immigrazione e Cittadinanzazoıo and G. Savio, La nuova disciplina delle espulsioni risultante dalla legge I29/20II. www.asgi.it/public/parser_download/.../savio_relazione_firenze.pdf.

149 Frontex is taking care of the training of the Libyan police and of the transfer of technology.

iso F. Pastore, supra n.I35, at 5. 


\section{(2) Spanish practice}

As regards Spain, several different geographical areas need to be distinguished according to the countries of origin of the immigrants:

- Mediterranean side: The main neighbouring country is Morocco, with which Spain has signed a readmission agreement. In the nineties, this area was important as a source of migration. In this period many Moroccan citizens arrived illegally by boat. Many people died every year in their attempt to cross the Straits of Gibraltar. However, after installing the SIVE (Sistema Integrado de Vigilancia Exterior), an electronic surveillance mechanism installed along the Southern coast of Spain and also in the Canary Islands, irregular Moroccan migration decreased.

- Atlantic side: In this area, Senegal and Mauritania can be identified as the two main sending countries. Both of them have signed specific agreements with Spain. Since the implementation of the SIVE mechanism, other irregular immigration flows have been diverted toward the Atlantic side. Furthermore, after the agreement reached with Morocco on the readmission of Sub-Saharan people, immigrants started travelling from Mauritania to Spain, to finally arrive in the Canary Islands. And as a side-effect, when Spain obtained Mauritanian cooperation on irregular immigration (in 2003) the flows moved further south, to Senegal and Côte d'Ivoire. ${ }^{\mathrm{IrI}}$ The situation of migrants in this region is complex because sometimes they must stay in Centres for long periods, waiting to be identified and returned without any concrete legal status. ${ }^{\mathrm{I} 2}$ The situation in the Canary Islands is also intricate. ${ }^{\mathrm{I53}}$

- Latin America: These countries are the traditional countries of emigration to Spain. ${ }^{\mathrm{I} 4}$ The principal sending country is Ecuador, followed by Colombia, Argentina, Bolivia, Peru and Venezuela. 55 These countries represent some of the main sources of irregular immigration. Indeed, many undocumented migrants from these countries arrive as tourists and overstay after the maximum period allowed by this legal status (three months). ${ }^{156}$ Spain has signed various bilateral readmission agreements with different Latin American countries.

At present, under Spanish immigration legislation (Ley Orgánica de Extranjería), a maximum of 40 days' internment is allowed in any case. ${ }^{\mathrm{I} 7}$ This internment takes place in special centres for

${ }_{\text {I5I }}$ As a report highlights, "2006 was the highest point in the arrival of these boats to Canary Islands, when 25,000 immigrants arrived that summer."

i52 See CEAR 2008 Annual Report, Section 9.

${ }^{153}$ See S. Carrera, 'The EU Border Management Strategy FRONTEX and the Challenges of Irregular Immigration in the Canary Islands', CEPS Working Document No. 26I/March 2007, available at http://aei.pitt.edu/7385/r/I482.pdf.

${ }^{154}$ J. Peixoto, A socio-political view of international migration from Latin America and the Caribbean: the case of Europe, November 2005, Expert group meeting on international migration and development in Latin America and the Caribbean. Population Division Department of Economic and Social Affairs United Nations Secretariat Mexico City, 30 November - 2 December 2005. Available at http://www.un.org/esa/population/meetings/IttMigLAC/Po7_JPeixoto.pdf.

${ }^{155}$ See Country Report on Spain: Undocumented Migration: Counting the Uncountable. Data and trends across Europe funded under the 6th Framework Programme of the European Union. Undocumented Migration. Counting the Uncountable. Data and Trends across Europe. Report drafted by C. González-Enríquez, January 2009.

${ }^{156}$ Ibid. at 8.

157 Ibid. 
undocumented migrants (Centros de Internamiento de Extranjeros - CIEs). ${ }^{158}$ During this period, the authorities (the police, administrative and judicial authorities) must identify and return the immigrant. In the event that this is not possible, he or she must be freed. This situation often happens when there is no readmission agreement with the country of origin. ${ }^{\mathrm{I} 9}$

Within this general framework, we will now analyse the return of immigrants, taking into account the fact that the migration flows originate in Africa because of the implications for EU migration policy. Over recent years, immigration from African countries to Spain has significantly increased. ${ }^{160}$ As a result, the Spanish government has adopted a new strategy towards Africa in the context of migration. ${ }^{16 \mathrm{I}}$ Consequently, it has signed various agreements related to the management of migration flows with African countries of origin or the transit of immigrants. ${ }^{162}$ In this new approach, migration is taken to be closely linked with the development of the countries of origin, and this is reflected in the different framework cooperation agreements recently concluded. Moreover, the various readmission agreements which have been signed are particularly relevant for the present analysis. ${ }^{163}$

On the west African coast, readmission agreements have been signed with Cape Green, Mali, Guinea Conakry, Guinea-Bissau and Nigeria. ${ }^{164}$ These agreements include not only measures to fight irregular immigration but also cooperation with the states in the region. As a direct consequence, a notable decrease in irregular immigration flows coming from this area has been observed over the past two years. ${ }^{165}$

is8 See D.Boza Martínez, et. al., (coor.), La nueva regulación de la inmigración y de la extranjería en España. Régimen jurídico tras la LO 2/2009, el Real Decreto 557/20II y la Ley I2/2009 ( Tirant lo Blanch, Valencia, 2012).

59 Country Report on Spainsupra n. 155 The Report states that most sub-Saharans who arrived by boat until 2006 were freed.

ז60 S. Marcú, 'España y la geopolítica de la inmigración en los albores del siglo XXI', Cuadernos Geográficos, 40 (2007-I), 3I-5I.

16r See "Plan de Acción para el África Subsahariana" (Plan África 2006-2008. Ministerio de Asuntos Exteriores y de Cooperación. Dirección General de Comunicación Exterior) approved by the Spanish government in 2006.

${ }_{162} \mathrm{M}^{\mathrm{a}}$ Asunción Asín Cabrera, classifies them into three categories: "Acuerdos relativos a la regulación y ordenación de flujos laborales, "Acuerdos de readmisión de personas en situación irregular", "Acuerdos marco de cooperación en materia de inmigración”, Los acuerdos bilaterales suscritos por España en materia migratoria con países del continente africano: especial consideración de la readmisión de inmigrantes en situación irregular, $\mathrm{IOReDCE}(2008)$ 165-188.

${ }^{163}$ In the first category must be included, for instance: Acuerdo Marco de Cooperación en materia de inmigración entre el Reino de España y la República de Gambia, hecho «ad referendum» en Banjul el 9 de octubre de 2006 (B.O.E. $n^{\circ} 3$ IO de 28/12/2006), Acuerdo de Cooperación en materia de inmigración entre el Reino de España y la República de Guinea, hecho «ad referendum» en Conakry el 9 de octubre de 2006 (B.O.E. n 26, de 30/r/2007 y Corrección de Erratas, B.O.E. nº 80, de 3/4/2007 and El Acuerdo Marco de Cooperación en materia de inmigración entre el Reino de España y la República de Cabo Verde, hecho "ad referéndum" en Madrid el 20 de marzo de 2007 (B.O.E. nº 39, de I4/2/2008).

${ }^{164}$ Protocolo entre el Gobierno de España y el Gobierno de la República Argelina Democrática y Popular sobre circulación de personas, hecho en Argel el 3I de julio de 2002 (B.O.E. $n^{\circ} 37$ de I2/2/2004); Acuerdo entre el Reino de España y la República de Guinea- Bissau en materia de inmigración, hecho en Madrid el 7 de febrero de 2003 (B.O.E. $\mathrm{n}^{\circ} 74$ de 27/3/2003); Acuerdo entre el Reino de España y la República Islámica de Mauritania en materia de inmigración, hecho en Madrid el I de julio de 2003 (B.O.E. $n^{\circ}$ I85 de 4/8/2003).

165 Ibid. 
The bilateral relationship with Morocco deserves particular attention. Spain has signed successive return agreements with Morocco as a country of origin and transit. ${ }^{166}$ The events in 2005, when immigrants tried to cross the border by trespassing across fences into Ceuta and Melilla (Spanish autonomous cities in Africa), highlighted the difficulties in the implementation of the bilateral agreement. ${ }^{167} \mathrm{~A}$ difficult question concerns the situation of sub-Saharan citizens who crossed Moroccan territory in order to reach the Spanish coast by boat, frequently in precarious vessels (called pateras in Spanish). The situation of these people used to be problematic, because for some years Morocco refused to accept their return when they were caught in Spanish waters or along the coastline. This situation has become highly controversial with the construction of the Melilla border fence as a border barrier between Morocco and the Spanish city of Melilla to stop illegal immigration. ${ }^{168}$

With regard to the content of these readmission agreements, it must be underlined that the term 'readmission' is used in a broad sense to include both nationals and non-nationals from the contracting parties. ${ }^{169}$ As usual, under these agreements the main objective is sending back the undocumented migrants who are present in the territory of the contracting parties. States assume the obligation to facilitate their transport and to readmit them to the State requested. ${ }^{170}$ These agreements regulate the different reasons for which a stay can be considered irregular, and the readmission procedure. ${ }^{17 \mathrm{I}}$ With regard to the readmission of nationals of the Contracting Parties, the commitment is largely accepted by the African States with which Spain has signed agreements. ${ }^{172}$ On the other hand, the readmission of third-country nationals has only been accepted by a few States. ${ }^{173}$ The execution of the expulsion of undocumented migrants should be made, in principle, by direct transfer to the

166 See Acuerdo de 13 de febrero de 1992 entre el Reino de España y el Reino de Marruecos relativo a la circulación de personas, el tránsito y la readmisión de extranjeros entrados ilegalmente (B.O.E. $\mathrm{n}^{\circ}$ Ioo de 25/4/ 192 y Corrección de Erratas, B.O.E. $\mathrm{n}^{\circ} \mathrm{130}$, de 30/5/1992).

${ }^{167}$ See I. González García, 'El Acuerdo España-Marruecos de readmisión de inmigrantes y su problemática aplicación: las avalanchas de Ceuta y Melilla', XXII Anuario Español de Derecho Internacional (2006) 255-284. A. Chueca analysed the situation of irregular immigration on the occasion of the massive cross of borders in P. Aguelo Navarro y A. G. Chueca Sancho, 'Ceuta y Melilla. Los derechos de los inmigrantes en situación irregular', 36 Abogacía Española (2006) I4-I7.

r68 R. Mindernov, 'At Spanish Enclave, a Debate Over What Makes a Border', The New York Times, 24 November 2014.

169 F. Vacas Fernández, Los Tratados bilaterales adoptados por España para regular y ordenar los flujos migratorios, (Dykinson,Madrid, 2007) 191-203.

${ }_{170}$ The terminology in Spanish refers to the return procedure as "alejamiento efectivo" of the undocumented migrant to the requested State (Estado requerido).

${ }^{171}$ For a detailed analysis of the agreements, see A. G. Chueca Sancho, 'Inmigración y Tratados internacionales celebrados por la U.E.: Los Tratados de Readmisión', Universidad de Zaragoza, September 2003, available at http://www.unizar.es/union_europea/files/Readmision.pdf.

${ }^{172}$ Surprisingly, the exception is Morocco, which is not applying this clause. Other African countries have undertaken an obligation to readmit their nationals, provided that it shall be presumed that the concerned person is a national of the requested Contracting Party.The main obstacle to the implementation of these agreements consists in the accreditation or presumption of nationality by the requested State. In this regard, a complex administrative procedure for the identification of immigrants is undertaken when it is not possible to obtain the documents specified in each agreement.

${ }_{173}$ See the Agreement between Spain and Morocco in 1992, and the treaty concluded by Spain with the Islamic Republic Mauritania in 2003. 
country of origin or by a "transit" through the territory of another State. ${ }^{174}$ Readmission agreements also contain specific provisions related to the repatriation procedure. ${ }^{175}$

Special attention should be given to the protection of human rights. Although, in general, these readmission agreements encompass different human rights clauses, not all of them guarantee the same degree of protection of immigrants' rights. ${ }^{176}$ Thus, the first readmission agreements concluded by Spain with African countries do not contain explicit human rights provisions, e.g. the agreement signed with Morocco in 1992. ${ }^{177}$ However, in the successive readmission agreements signed in the 2000's, a greater degree of protection can be appreciated, e.g. the Protocol between Spain and Algeria of $2002 .{ }^{178}$ From 2003 onwards there is a trend to include human rights clauses in bilateral readmission agreements, as in the case of the agreements signed by Spain with Guinea Bissau and Mauritania. ${ }^{179}$ The insertion of such human rights provisions in the preamble and in the articles of agreements requiring the Contracting Parties to comply with human rights standards becomes crucial for guaranteeing that the removal of immigrants is carried out with complete protection of their rights, in particular taking into account the situation of their countries of destination. Despite this positive practice, as some scholars have pointed out, there is still an important gap in the protection of human rights because of the lack of inclusion of judicial guarantees (recognized in article 6 of the ECHR and

${ }^{174}$ However, direct return is not always feasible, due, among other circumstances to the viability or lack of a direct flight to the destination country. In these cases, it is necessary to make a request to another state to authorize transit through its territory to enforce the removal.

${ }_{175}$ Such as the submission of the application for readmission, the identification of the competent authority, the timing of application submissions, methods and means of transportation, baggage allowance and the assumption of costs or expenses caused by the return.

${ }^{176}$ International law scholarship in Spain has contributed an extensive literature on the issue. See, amongst others: A. Chueca Sancho, 'El ius migrandi en el derecho internacional de las migraciones', in M. Balado Ruiz-Gallegos, Inmigración, Estado y Derecho: perspectivas desde el siglo XXI (Dykinson, Madrid, 2008); A. Chueca, V. L. Gutiérrez Castillo, I. Blázquez Rodriguez (eds) Las migraciones internacionales en Mediterráneo y Unión Europea (Huygens, Barcelona, 2009); J. A. González Vega, 'La inmigración irregular y la política convencional: Examen de la práctica española', in J. De Lucas (ed.) La igualdad en los derechos: claves de la integración (Dykinson, Madrid, 2009); F. M. Mariño Menéndez, La Convención de Ginebra sobre el Estatuto de los Refugiados, in Manuel Balado Ruiz-Gallegos, Inmigración, Estado y Derecho: perspectivas desde el siglo XX, 2008; I. Riera, Emigrantes y refugiados (El derecho universal de la ciudadanía) (Intermón Oxfam, 2002).

17 The only human rights provision is Art. 8, which stipulates that transit can be denied in the case that the individual is at risk of suffering bad treatment (sic) in the State of destination. ("cuando el extranjero corra riesgo de sufrir malos tratos en el Estado de destino"). The agreement does not include a specific mechanism to protect the rights of immigrants.

${ }_{178}$ Protocol between the Government of the Kingdom of Spain and the Government of the Democratic and Popular Republic of Algeria on the movement of people (Protocolo entre el Gobierno del Reino de España y el Gobierno de la República Argelina Democrática y Popular sobre circulación de personas), signed on 3Ist July 2002. In Art. 8, the Protocol states: "This Protocol is held in strict compliance with the commitments made in protecting human rights and will not affect the obligations under international agreements and conventions concluded by the parties."

179 See the Agreement with Guinea-Bissau (Art. XIX) signed on $7^{\text {th }}$ February 2003 and Agreement with Mauritania (Art. XXIII) signed on $\mathrm{I}^{\text {st }}$ July 2003. With similar language, these articles state: I. The Contracting Parties shall not use force, torture or cruel, inhuman or degrading treatment in the application of this Agreement. 2. Each Contracting Party will: i) immediately inform the Embassy of the other Party of the detention of a national of that country for a breach of the rules and/or regulations on immigration; ii) not subject the detainee to undue force, torture or cruel, inhuman or degrading treatment; iii) allow unlimited access to the Embassy officials of the other Contracting Party to contact the nationals of that Contracting Party who are under custody and hold talks with them private." 
article 47 of the European Union Charter of the Fundamental Rights), such as the judicial review of the return decision. ${ }^{180}$

Turning now to the impact of the Return Directive on cooperation with these countries, picturing the possible future scenario, it can be said that the Return Directive may provide new grounds for the protection of immigrants' human rights during their "readmission" or removal, including procedural guarantees (not included in the readmission agreements) with the limitations underlined above. ${ }^{18 \mathrm{I}}$ The modification of the Spanish Immigration Act tried to adapt it to EU legislation (including the Return Directive) providing new elements with which to assess the impact of the Directive on internal legislation and Spanish practice in this field. The implementation of the Directive so far as has not introduced significant changes. ${ }^{182}$ However, the Directive aims could reinforce the strategy adopted by Spain, aimed at assisting African countries. ${ }^{183}$ This new approach in Spanish external policy emphasises the need for cooperation in the development of the countries of origin or transit as an effective means to achieve the objective of fighting irregular immigration. ${ }^{184}$

\section{CONCLUDING REMARKS}

As mentioned previously, the main aim of this article is to throw light on the current EU dilemmas on immigration from the angle of international human rights law. The EU faces currently many challenges, including those related to the management of migration flows. The current system, as shown, reflects the complexity of the issue; it seems necessary to review certain aspects of the existing immigration system in order to improve it.

A well-designed EU immigration system is essential to guarantee basic human rights to all migrants regardless of their legal status, in particular with regard to immigration by sea. The interests of EU Member States' in controlling illegal immigration must be balanced with compliance with their international human rights obligations.

The Lisbon Treaty brought about new elements, in particular, at the decision-making level, to build up a true European common policy on irregular migration. Furthermore, under the Lisbon

I80 See Ma Asunción Asín Cabrera, supra n. 162, at 185.

I8I Ibid.

${ }^{182}$ As the report on the implementation states, "the Return Directive itself also cannot achieve its original aims as long as it recommends administrative detention as a legitimate tool in European migration policies”, see supra n. 96 at 44 .

${ }^{183}$ The framework program for Spanish international cooperation in Sub-Saharan Africa (Plan Director de la Cooperación Española 2005-2008 con los países del África Subsahariana) encompasses financial aid for development.

${ }_{184}$ With regard to the measures adopted by the Spanish government for cooperation with African countries with which Spain has signed bilateral readmission agreements, can be mentioned: Real Decreto 1542/2006, de I5 de diciembre, por el que se crea la Consejería de Trabajo y Asuntos Sociales de la Misión Diplomática Permanente de España en la República de Senegal, "con el deseo de impulsar el desarrollo de las relaciones bilaterales hispano-senegalesas en el ámbito laboral y social, con el objetivo especial de establecer flujos migratorios y hacer posible la contratación en origen de trabajadores provenientes de la República de Senegal...», BOE n 310, de 28 de diciembre de 2006; el Real Decreto 187/2007, de 9 de febrero, por el que se regula la concesión de una subvención extraordinaria a la República Islámica de Mauritania para la mejora del control de sus fronteras y lucha contra la emigración ilegal, BOE no 39, de I4 de febrero de 2007; El Acuerdo entre el Reino de España y la República Argelina Democrática y Popular sobre supresión recíproca de visados en pasaportes diplomáticos y de servicio, hecho «ad referendum» en Argel el I3 de marzo de 2007, BOE n 28, de I de febrero de 2008. 
Treaty, the European Charter of Fundamental Rights is binding and EU accession to the ECHR will be effective.

At first sight, the Return Directive may be seen as an accurate legal framework for the harmonisation of policies and legislation, but the devil is in the details. The laudable efforts made during the negotiation of the Return Directive to reconcile the protection of human rights with fighting illegal immigration seem to be insufficient to grant an adequate level of protection to immigrants. From a theoretical point of view, such a common legal framework is needed to create an authentic common migration policy. However, certain aspects of the Return Directive remain ambiguous and may lead to situations in which migrants' human rights are not guaranteed. The success or the failure of the EU legislation depends (as always) on the practical measures applied by each Member State in its implementation.

The features of migration flows highlight the need for EU Member States to enhance cooperation with countries of origin and transit, not only in immigration control activities but also, and most importantly, in the achievement of a certain level of development in the regions of origin of immigrants. This implies a shift towards a broader approach to migration, including both preventive measures and the application of the principle of "solidarity" between EU Member States and the countries of origin and transit of immigrants. A more realistic approach is needed in this area in order to give an appropriate response to the question of illegal immigration. Otherwise, the EU risks this particular field becoming a Sisyphean task in the quest for the compliance with international human rights law. 